\title{
Payroll Share, Real Wage and Labor Productivity across US States
}

\author{
Ivan Mendieta-Muñoz ${ }^{*}$, Codrina Rada ${ }^{\dagger}$, Ansel Schiavone \\ and Rudi von Arnim ${ }^{\S}$
}

\section{Working Paper No. 121}

April 15 ${ }^{\text {th }}, 2020$

\begin{abstract}
This paper analyzes regional contributions to the US payroll share from 1977 to 2017 and the four major business cycles throughout this period. We implement two empirical exercises. First, we decompose the US payroll share across states. Utilizing a Divisia index decomposition technique yields exact contributions of real wages, employment structure, labor productivity and relative prices across the states to the aggregate change in the payroll share. Key findings are that the decline in the aggregate (i) is driven by decoupling between real wage and labor productivity; and

\footnotetext{
* Assistant Professor, Department of Economics, University of Utah

Corresponding author: rada@economics.utah.edu; Associate Professor, Department of Economics, University of Utah.

$\$$ PhD Candidate, Department of Economics, University of Utah

$\S$ Associate Professor, Department of Economics, University of Utah
}

The authors gratefully acknowledge financial support from the Institute for New Economic Thinking (INET). We thank Peter Skott, Thomas Michl and participants to the Eastern Economic Association Conference, Boston, 2020, for their comments and suggestions.
\end{abstract}


(ii) is initially driven by the rust belt states, but subsequently dominated by relatively large states. Second, we employ mixture models on real wages and labor productivity across US states to discern whether distinct mechanisms appear to generate these distributions. Univariate models (iii) indicate the possibility that two distinct mechanisms generate state labor productivities, raising the question of whether regional dualism has taken hold. Lastly, we use bivariate mixture models to investigate whether such dualism and decoupling manifest in the joint distributions of payroll shares and labor productivity, too. Results (iv) are affirmative, and further suggest a tendency for high performing states to have relatively high payroll shares initially, and low payroll shares more recently.

\section{https://doi.org/10.36687/inetwp121}

JEL Codes: D33, C43, O41, O5

Keywords: labor share; US states; Divisia decomposition; mixture models 


\section{Introduction}

There is compelling evidence that the United States (US) labor share has declined in recent decades. Several important studies investigate the phenomenon on the basis of sectoral and firm-level data.

Rognlie (2015) associates the majority of the rise in the profit share to markups over the user costs of capital in the real-estate sector, and thus views it as a reflection of imputed rents on the one hand, and rising real estate prices on the other. Karabarbounis \& Neiman (2014) link the fall in the labor share to the decline in the relative price of investment goods. This implies a rise in the capital-output ratio and, under the assumption of an elasticity of substitution greater than unity, a rise in the profit share. Both Rognlie (2015) and Karabarbounis \& Neiman (2014) imply that the secular shift away from manufacturing in the US cannot explain the recent decline in the labor share. Similarly, Autor et al. (forthcoming) attribute the downward trend in the labor share to the rise in within-industry market shares of highly productive firms. These "superstar" firms hold acute technological advantages over their competitors, which they use to expand market shares. Importantly, similar patterns are discernable across six sectors. Again, manufacturing is no outlier.

Other studies highlight the importance of traded vs. non-traded activities. Elsby et al. (2013) maintain that increased foreign competition and subsequent offshoring of labor-intensive activities has been a critical factor in the decline of the labor share since the 1980s. Manufacturing is most obviously affected in this manner, whereas the service sector is largely spared due to the generally non-tradable nature of its outputs. Utilizing a Divisia index decomposition of the labor share into four components (real wage, employment structure, labor productivity and relative prices) in fourteen sectors, Mendieta-Muñoz et al. (2019) complement and extend these findings. Their results indicate that manufacturing, and specifically the large and growing gap between the sector's labor productivity and real wage contributions, indeed plays an important role in the overall decline of labor's share. However, so do other progressive service sectors, particularly finance, information technology and wholesale trade as found by Taylor \& Ömer (2019) as well. While employment shares in these progressive sectors are falling sharply, those of less progressive sectors - health, education, entertainment - are rising. Importantly, these latter activities have relatively high labor shares but low real wages. This is an interesting finding for two reasons. First, it suggests that Autor et al. (forthcoming)'s story of intra-industry productivity driven decline is perhaps incomplete. Second, it indicates a divergence in meaning between two important macro variables: the real wage and the labor share. Structural shifts of this type may in fact raise the share of income going to labor-but workers are worse off than before, since real wages are now lower.

We add to this literature a systematic (and, to our knowledge, novel) analysis of 
regional contributions to changes in the US private sector payroll share 1 Our paper thus approaches the topic through a different lens. Nevertheless, connections to key themes drawn out above can be made. Crucially, we document a decoupling of real wages from labor productivity; observe that the rust belt states and deindustrialization matter especially throughout the 1980s; and provide suggestive evidence for regional dualism, i.e. an increasing divide between progressive and stagnant states. The remainder of this introduction discusses our contribution in more detail.

First, the measure of the labor share put forth here includes only private activity, but excludes the real estate sector, and excludes incomes from proprietors and selfemployment. In the public sector, the profit share is assumed to be zero. The real estate sector features elevated profit shares due to imputed rents, as previously discussed. The apportioning of proprietors' income as remuneration for their labor requires further assumptions, and we eschew related controversies by focusing on wages and salaries cum supplements of employees. In other words, our focus lies on the payroll share.

We implement two empirical exercises. Following Mendieta-Muñoz et al. (2019), we use a Divisia index decomposition of US state-level data. This method provides exact contributions of four critical components (real wages, employment structure, labor productivity and relative prices) to the change in the aggregate index of the payroll share over the chosen period. Second, we utilize mixture models. These models are useful to identify whether a distribution is likely to be generated by one or more data generating processes. While the method does not speak to the underlying mechanism(s) itself, it can powerfully illustrate degrees of heterogeneity, and changes therein over time. Our analysis with both methods covers the period from 1977 to 2017. We provide results for the entire period, but as well four major business cycles contained in this sample 2 These business cycles are roughly similar in length, and extend from peak-to-peak: 1979-1989, 1989-2000, 2000-2007 and 2007-2017. Of course, the first of these brushes over the double-dip in the early 1980s, and the endpoint of the last is not a peak. Still, our key results reveal important patterns.

Specifically, we observe decoupling of real wages and labor productivity. The Divisia decomposition clearly suggests (i) that changes in the payroll share are dominated by these two components, and (ii) that contributions of the latter outweigh the former. This is broadly consistent with previous findings that within-unit changes overwhelm across-unit (reallocation) effects. The decline in the aggregate implies that downward decoupling - growth of productivity exceeding that of real wages eclipses upward decoupling.

\footnotetext{
${ }^{1}$ Kehrig \& Vincent (2018) investigate the decline of the labor share at the establishment level in the US manufacturing industry. Table 4 (p.40, and corresponding discussion) indicate, based on a shift-share analysis, that the majority of the decline of the labor share is due to within-region adjustments. In contrast, we focus on regional issues, rather than manufacturing.

${ }^{2}$ In this paper the business cycles are identified according to the National Bureau of Economic Research https://www.nber.org/cycles/cyclesmain.html
} 
Further, deindustrialization plays a central role in the decline of the payroll share in the early period of our sample. Our disaggregation provides of course no detail on sectoral issues per se. However, rust belt states, including Ohio, Indiana and Pennsylvania, drive the fall in the payroll share from 1979 to 1989. Subsequently, a large state effect emerges. New York, California and Texas provide significant negative contributions, while positive contributions by Florida (and Louisiana, a middling state by size) provide a small buffer on the overall decline of payroll share.

The mixture models indicate that regional dualism in terms of states' labor productivities might have taken hold, though not in terms of real wages. The concept of dualism originates in development economics. It refers to the coexistence of modern high-growth and "backward" stagnant activities. In the former, output per worker can be increased consistently via innovation, capital accumulation or economies of scale, whereas the latter see only sporadic and small gains in productivity (Lewis, 1954: Bhaduri \& Skarstein, 2003). Economic dualism could manifest geographically if certain regions are more conducive to progressive (or stagnant) economic activities, due to historical, social, institutional or political factors. Regional dualism, by extension, implies the coexistence of progressive and stagnant state or regional economies. By extension, regional dualism implies lack of convergence, a phenomenon that has emerged in the last few decades across the US states (Magrini et al. (2015)).

Our results based on univariate mixture models across states indicate that the distribution of real wages is generated by a single mechanism, whereas that of labor productivity is generated by two distinct mechanisms. This result pertains to the entire period. Labor productivity displays a mixture of distributions in two of the four cycles (1989-2000 and 2000-2007), whereas real wages feature a single distribution across all four sub-periods. In the bivariate analysis, we investigate the joint distribution of states' productivity performance and payroll shares across the four cycles. Results suggest that (a) on balance, two different mechanisms generate these joint distributions; that (b) the difference between distributional means is initially relatively high for payroll shares, and ultimately high for productivity performance; and that (c) the first two cycles suggest a positive correlation between performance and payroll share, whereas the latter two suggest a negative correlation.

This last point particularly stands out. In a nutshell, a widening gap between productivity and real wage growth specifically in progressive states is driving the aggregate payroll share down. This finding echoes those identified by others $(\mathrm{Au}-$ tor et al. , forthcoming; Kehrig \& Vincent, 2018, Mendieta-Muñoz et al., 2019, Taylor \& Ömer, 2019). These studies document such downward decoupling in the most progressive units - either in large and innovative firms, or in dynamic, high productivity sectors.

In summary, in our regionally disaggregated data set, changes in payroll shares are far from uniform. Instead, they differ across time and space: the rust belt states matter early, possibly because of deindustrialization, and large states are in 
the driver's seat later. The latter half of the sample shows striking heterogeneity in state-level productivity distributions. Across all of it, the unifying feature is a decoupling of growth rates of real wage and labor productivity, specifically in the progressive states. The remainder of the paper is organized as follows. The following section describes data, decomposition technique and results. Section 3 presents univariate mixture models on real wage and productivity distributions by states, and bivariate mixture models of productivity performance and payroll shares by states. Section 4 concludes.

\section{Decomposition of the US payroll share by state}

This section describes data, method and results of the Divisia decomposition. We present an overview of the method in Section 2.1. and detailed results for the entire period (1977-2017) and the four major business cycles therein in Section 2.2. In the following paragraphs, we introduce data used and the resulting measure of the payroll share.

The labor share measures the portion of total income flowing to labor in a given time period. A variety of definitions exist in the literature. Our measure is simply the ratio of employee compensation (wages and salaries plus supplements) to value added net of taxes (compensation plus gross operating surplus). Since our measure for compensation excludes income of proprietors and the self-employed, we refer to our measure as the payroll share rather than the labor share.

We include only private industries, and hence exclude all government activities. By definition, the public sector does not have operating surpluses, and would thus not add substantially to the analysis. We also exclude real estate activities from our dataset. A large portion of income in this sector comes in the form of imputed rent, whereby owners of real estate are presumed to have paid rent to themselves. This obscures the meaning of income at the heart of this paper, and we thus exclude it from our analysis. Further, in light of Rognlie (2015), we guard against bias in the labor share decline due to relative price increases in the real estate sector.

The data used consists of five state-level panels: compensation, gross operating surplus, nominal GDP, real GDP, and employment. All data were obtained via the Bureau of Economic Analysis (BEA), which compiles data from a variety of sources including the Bureau of Labor statistics (BLS), US Department of Labor, and various other federal and state government agencies. The time period for each panel is 1977-2017, with annual observations. All series measure private industry less real estate and rental leasing for a state in a given year ${ }^{3}$

\footnotetext{
${ }^{3}$ In 1997, the BEA and BLS transitioned from the Standard Industrial Classification (SIC) system to the North American Industry Classification System (NAICS). Thus, our complete panels are constructed by linking the 1977-1997 SIC and 1998-2017 NAICS data. To exclude real estate activities, we take the "private industry" observation for the given series and subtract "real estate and rental and leasing" for NAICS data and the corresponding activities for SIC data based on the
} 


\section{[FIGURES 1 AND 2 ABOUT HERE]}

Figure 1 depicts the time series of the thus obtained US payroll share, as well as the labor share and employee share. The latter two are headline measures issued by the BLS. The labor share is the ratio of total labor compensation (employee and proprietor) to output. The employee share excludes proprietor labor compensation. Thus, the payroll share is similar in that it excludes proprietor labor compensation, but also removes compensation of those who are self-employed as well as real estate and rental and leasing activities (compensation and output).

In general, the movements of the three series are quite similar, despite the difference in levels. Like other measures of the functional distribution of income, business cycle fluctuations are clearly visible. Nevertheless, a clear downward trend is observed in all three series. Over the entire period, the US payroll share declined 3.1 percentage points.

However, declining payroll shares are not uniformly observed across all states. Figure 2 charts state payroll shares together with the aggregate, see additionally Figure D.1 in Appendix D. The payroll share rose in about a third of the states, while it declined or remained constant in the rest. Very roughly, coastal states have seen more pronounced declines in payroll shares. However, and as will be seen further below, changes in state payroll shares do not always reflect states' contributions to changes in the national payroll share. This is due to the importance of a state's weight, in terms of wage bill and value added, in the decomposition method - which is the topic of the following subsection.

\subsection{The Divisia decomposition method}

The payroll share in an economy is generally defined as the ratio of nominal values of the wage bill and value added. If there are $j$ regions or states the payroll share can be written as the ratio of the sum of state level nominal wage bill and the sum of state level nominal value added. Following simple algebraic manipulations, we

concordance tables supplied by the BLS. For employment data, the "private industry" observation must first be constructed by summing "private nonfarm wage and salary employment" and "farm wage and salary employment" before subtracting the real estate term. See Appendix A for more detail. Because we do not consider sectoral data in more detail, we are not concerned with the general change in industry classification. 
rewrite aggregate payroll share as follows 4 .

$$
\psi=\frac{\sum_{j=1}^{n} p_{j} \omega_{j} \lambda_{j}}{\sum_{j=1}^{n} p_{j} \varepsilon_{j} \lambda_{j}}
$$

where $\omega_{j}, \varepsilon_{j}, \lambda_{j}, p_{j}$ indicate real compensation or the nominal wage deflated by the state price level $P_{j}$, labor productivity, employment share and terms-of-trade at the state level. The payroll share can be decomposed into several contributing factors. Changes in the state real wage and labor productivity amount to shift effects; changes in the regional structure of the economy as measured by the state employment shares are perceived as structural or share effects while changes in the terms-of trade are market structure effects. The following are the discrete format terms following from the decomposition:

$$
\begin{aligned}
D_{\text {comp }} & =\exp \left[\sum\left(\phi_{j, t}+\phi_{j, t-n}\right) / 2 \ln \left(\omega_{j, t} / \omega_{j, t-n}\right)\right] \\
D_{\text {str }} & =\exp \left[\sum\left[\left(\phi_{j, t}+\phi_{j, t-n}\right) / 2-\left(\theta_{j, t}+\theta_{j, t-n}\right) / 2\right] \ln \left(\lambda_{j, t} / \lambda_{j, t-n}\right)\right] \\
D_{\text {price }} & =\exp \left[\sum\left[\left(\phi_{j, t}+\phi_{j, t-n}\right) / 2-\left(\theta_{j, t}+\theta_{j, t-n}\right) / 2\right] \ln \left(p_{j, t} / p_{j, t-n}\right)\right] \\
D_{\text {tech }} & =\exp \left[\sum\left(\theta_{j, t}+\theta_{j, t-n}\right) / 2 \ln \left(\varepsilon_{j, t} / \varepsilon_{j, t-n}\right)\right]
\end{aligned}
$$

where $\phi$ and $\theta$ are the weights, defined as the state's share of the aggregate nominal wage bill and the state's share of nominal value added, respectively. The ratio between the two eights $\phi / \theta$ represents payroll share of state $j$ relative to the US aggregate payroll share. The index for the change in the payroll share is then given by:

$$
D=D_{\text {comp }} D_{\text {str }} D_{\text {price }} D_{\text {tech }}^{-1}
$$

$D$ is simply the ratio of end-year value of the payroll share over the first-year value $\psi_{t} / \psi_{t-n}$, or the growth rate plus one, $D=g_{\psi}+1$. A positive change in state $j$ 's real wage contributes to a rise in the US payroll share, while a positive change in the state's labor productivity lowers the payroll share.

The interpretation of the structural and the terms-of-trade components (equations 3 and 4 are more nuanced. The $\ln \left(\lambda_{j}\right)$ term is negative if the employment

\footnotetext{
${ }^{4}$ Appendix B provides more detail on the specific decomposition here. Index decomposition analysis dates back to the 1970 s when it was used to assess the effect of changes in the structure of industrial production on energy demand. Decomposition techniques have since been refined and applied widely across disciplines including economics. For an example on growth and structural change, see Dietzenbacher \& Los (1998). Critically, the Divisia index decomposition has the desirable theoretical property of being a symmetric and additive indicator of relative change (Ang, 2004). Its discrete representation as a Törnqvist index is also a good approximation of the Fisher ideal index; for a discussion, see Dumagan (2002). We build here especially on Diewert (2010). See also Mendieta-Muñoz et al. (2019) for a similar application.
} 
share of state $j$ declines. However, if the state's payroll share is below the aggregate payroll share, the weight in equation 3 is negative since $\phi_{j}-\theta_{j}=\psi_{j} / \psi-1$. It follows that the aggregate payroll share increases when employment shares decline in states with lower than average payroll shares. This apparent improvement in the payroll share is not necessarily a positive development if the state that sheds labor (in either relative or absolute terms) is a state with higher than average real wage and labor productivity. In this case the change in the regional structure of the economy takes place towards states with higher payroll shares, yet a lower productivity and therefore a lower real wage in absolute terms.

The last component of the decomposition is the contribution from changes in terms-of-trade, equation 4. The term $\ln \left(p_{j}\right)$ is positive if the state price level grows faster than the general price level. The final effect on the change in the aggregate payroll share depends, once again, on the state's relative payroll share. Positive changes in relative prices will add to the aggregate payroll share in states with higher relative payroll shares. The reason is that a relative price increase will increase the weight of states with higher payroll shares, driving up the aggregate payroll share.

\subsection{Results: Rust belt vs. large states, and decoupling of real wages from productivity}

This section presents decomposition results. We begin with the total contribution of each state, see Figure 3. New York had the greatest negative contribution of -.74 percentage points followed by California (-.62), Pennsylvania (-.41) and Texas $(-0.33$, see also Table 1 in Appendix C). Connecticut, Indiana, Michigan, New Jersey and Ohio also contributed significantly to the decline, as did North Carolina, Georgia, and, in the north-west, Washington state. At the other end of the spectrum, Florida exhibited the greatest positive contribution of 0.20 percentage points, followed by Louisiana with 0.16 , and Virginia, Kentucky, Arizona and Minnesota with about 0.07 percentage points on average each.

To illustrate the importance of weighting in the decomposition, consider Texas in more detail. Its overall payroll share increased between 1977 and 2017 by 2.2 percentage points: real wages grew faster than labor productivity in all but the third cycle. However, its total contribution to the aggregate is negative. The reason is that its share in nominal value added is much larger than its share of the national wage bill. In other words, its payroll share is below the US average, and this in turn amplifies the (negative) effect of Texas' labor productivity growth on the national payroll share.

\section{[FIGURE 3 ABOUT HERE]}

Next, we turn to aggregate component contributions. The key finding is that compensation and productivity dominate; employment structure and relative price changes are relatively minor factors. Real wages show a positive contribution of 33.6 
percentage points, and labor productivity a negative contribution of 36.6 percentage points. See Figure 4 for a graphic representation 5 This finding is consistent with Mendieta-Muñoz et al. (2019), who argue that changes in the payroll share are primarily due to differences between real wage and labor productivity growth. The evidence here is thus consistent with downward decoupling within sectors, rather than structural change across sectors. Put differently, we find that the fall in the payroll share is driven by intra-state decoupling of compensation and productivity, not shifts in state employment shares or changing relative prices.

Texas is the only state that stands out with a negative contribution of -0.20 from the structural component. The reason is - again - that Texas' payroll share remains below the nation's average. As a consequence, the observed increase in the share of employment of more than 2 percentage points has an overall negative impact.

\section{[FIGURE 4 ABOUT HERE]}

Let us now consider the four major business cycles contained in the sample. These are 1979-1989, 1989-2000, 2000-2007 and 2007-2017. At the beginning of the period, we lose two years of data ${ }^{6}$ However, comparing periods peak-to-peak when possible is preferable. Further, and as mentioned previously, the last cycle indeed does not end in a peak, and the first brushes over the second downturn at the onset of the 1980s. Nevertheless, clear patterns emerge.

Figure 5 displays aggregate contributions. During the 1979-1989 business cycle, the payroll share declined by 1.15 percentage points. The greatest negative contributors were from Michigan, Ohio, Pennsylvania, Illinois, North Carolina and Indiana $(-0.19,-0.17,-0.16$, and -0.10 in each of the last three states, respectively). These states experienced strong downward decoupling as the real wage lagged productivity growth. Florida and Texas stand out with relatively strong upward decoupling, and therefore contributed positively at 0.05 and 0.10 percentage points (see Table 2 in Appendix C).

\section{[FIGURE 5 ABOUT HERE]}

The 1989-2000 business cycle saw an increase in the national payroll share of 1.1 percentage points. Significant negative contributions arise in New York, Georgia and California $(-0.18,-0.10$ and -0.09$)$. Moreover, we observe a greatly diminished impact of rust belt states that previously drove the decline (see Table 3 in the

\footnotetext{
${ }^{5} \mathrm{An}$ aggregate real wage component contribution of 33.6 percentage points implies-ceteris paribus - an increase in the payroll share of 33.6 percentage points. Other components are interpreted analogously.

${ }^{6}$ Given its pro-cyclical behavior, the payroll share increased by about one percentage point between 1977 and 1979. Adding up changes in the aggregate payroll shares across the four cycles leads to an overall decline in the payroll share of 4.1 percentage points between 1979 and 2017.
} 
Appendix C). Louisiana, Texas, and Florida remained the greatest positive contributors at $0.19,0.14,0.10$ percentage points, respectively. It should be noted that while positive contributions from Texas and Florida came primarily from strong compensation growth, Louisiana's contribution is due mostly to a dramatic decrease in productivity. Labor productivity in the state actually fell by $5.3 \%$. Thus, while the direction of the contribution is the same for all three states, the reason behind Louisiana's positive contribution is not encouraging.

The payroll share declined most precipitously during the 2000-2007 business cycle by a total of 3.26 percentage points. Texas $(-0.92)$, previously a positive contributor to the aggregate payroll share, and California $(-0.53)$ had the largest negative effect (see Table 4 in Appendix C). High productivity growth relative to wages appears to be the source of the decline in these states. New York, on the other hand, bounced back and had a positive contribution of 0.18 percentage points: New York's productivity contribution in these years is considerably lower relative to previous cycles, but while the state's real wage contribution decreased as well, it did so by less.

In the current business cycle, the payroll share has continued its downward trend, falling by 0.78 percentage points (see Table 5 in Appendix C). California contributed -0.11 percentage points as its productivity growth continued to dominate that of compensation. Pennsylvania, Ohio and Illinois also followed their previous downward trend with $-0.13,-0.12$ and -0.09 percentage points. Texas has seen compensation rebound relative to productivity, resulting in a positive total contribution of 0.28 . The most striking development, however, is the dramatic reversal in New York's contribution. In the previous business cycle New York was the greatest positive contributor, but now the state has been leading the decline with a -0.59 percentage points. This shift appears to be due to a dramatic collapse in New York's compensation component.

The shift in importance from rust belt states to large states (in terms of value added) with regards to payroll share dynamics is an important finding derived from the Divisia method. To strengthen this claim, we run simple rank correlations between states' contribution to payroll share change in absolute terms, and their average value added share for each period. Unsurprisingly, positive and statistically significant correlation coefficients are observed for all four periods: 0.492, 0.405, 0.560 , and 0.618 , respectively. This correlation becomes stronger in the later two periods, indicating a strengthening in the relationship between the size of a state's economy and its contribution to changes in the payroll share.

It is further apparent that aggregate component contributions across the four business cycles differ starkly. During the last period (2007-2017), the aggregate contribution from productivity growth amounts to only -4.13 percentage points, or -0.4 percentage points on an annual basis. The aggregate contribution from real compensation growth per annum is 0.3 . In contrast, the corresponding averages across the preceding three cycles are 0.9 and -1.1 for compensation and productivity 
components, respectively.

In summary, we broadly identify three major results. First, rust belt states of Ohio, Michigan, Indiana, and Pennsylvania contributed significantly and negatively in the earliest cycle of 1979-1989, but developments there have since lost their potency. Second, in the ensuing years, a large state effect has emerged: California, Florida, Illinois, New York, and Texas consistently dominate contributions to the aggregate payroll share. Third, the gap between contributions from compensation and labor productivity drive changes in the payroll share. More specifically, upward decoupling between the real wage and productivity growth in states such as Florida, Louisiana, Arizona, Virginia or Kentucky have buffered the negative effects of downward decoupling in, among others, California, New York, Illinois, Pennsylvania or Texas. The latter group dominated overall and, as a result, the aggregate payroll share declined.

\section{State real wage, productivity and payroll share dis- tributions over time}

This section provides further evidence on state-level real wages, labor productivity, and payroll shares. Specifically, Section 3.1 investigates probability distributions of real wages and labor productivity across states, and Section 3.2 joint distributions of productivity performance and payroll shares across states. As before, we conduct this analysis for the entire period and also the four major business cycles. We utilize the same data. This brief introduction motivates the approach.

To begin, relative labor productivity and compensation data across the map of US states is shown in Figure 6. In the year 2017, productivity and real wages were significantly higher in large populous states such as Texas, California, New York and Illinois, and coastal states like Massachusetts, Connecticut, Delaware, and Washington. Results presented in Section 2.2 indicate that these are also the states that have dominated the negative contributions to the aggregate payroll share. Other states display much lower levels of labor productivity and real wage, and positive contributions to the US payroll share. Alaska and Wyoming are outlier states because of their extremely high productivity due to mining and oil extraction activities combined with very low populations.7 Louisiana and Oklahoma also have higher than average labor productivity due to the importance of extractive industries, but their economies are nevertheless significantly more diverse than Alaska and Wyoming.

\section{[FIGURE 6 ABOUT HERE]}

To explore probability distributions of real wages, labor productivity and payroll shares across states, we employ mixture models. A mixture model determines

\footnotetext{
${ }^{7}$ We exclude Alaska and DC from the analyses throughout this section. Wyoming is also excluded from the bivariate mixture model analysis. For details, see descriptions accompanying each figure.
} 
whether subgroups are likely to exist within a population. Put differently, a mixture model is a clustering algorithm. As mentioned previously, the method does not provide evidence on the specific mechanism(s) that generate these distributions, but powerfully illustrates statistical support for significant heterogeneity within the population. In our application, distributional means and variances are allowed to vary, but importantly, all underlying distributions are assumed to be Gaussian 8 The optimal mixture model (number of groups and parameter values) is selected among candidate models according to the maximum Bayesian information criterion (BIC) $9^{9}$ We implement the algorithm with $\mathrm{R}$ package mclust. For further documentation and references, see Scrucca et al. (2016).

Key findings can be summarized as follows. First, evidence presented in the following subsection suggests that the data generating processes of real wage and productivity have become increasingly dislocated. The distribution of real wages across states has maintained a relatively stable unimodal shape throughout all cycles, whereas the distribution of labor productivity is multimodal for the entire sample, and two cycles (1989-2000 and 2000-2007). Second, results from bivariate analyses in Section 3.2 of labor productivity and payroll shares raise the possibility of a regime change from one of high productivity-high payroll shares in the initial cycles to high labor productivity-low payroll shares in more recent cycles. The critical conclusion is that regional dualism appears to have taken hold.

\subsection{Univariate mixtures: Dualism in labor productivity}

We first apply the mixture model to real wage and labor productivity distributions across states for the entire sample, 1977-2017. Figure 7 reports results. The left panel indicates that the data generating process of $(\log )$ real wage is the same across all states. In contrast, (log) labor productivity appears to be driven by different phenomena across groups of states. More specifically, the resulting distribution for the real wage over the entire period remains unimodal. The mixture model for labor productivity produces a bimodal distribution, indicating the existence of two distinct clusters of states: one each with relatively low and high productivity levels. The states determined by the model to belong to the rightward "progressive" distribution for labor productivity are: California, Connecticut, Delaware, Illinois, Louisiana, New Jersey, New York, Texas, Washington, and Wyoming. With the exception of Wyoming and Louisiana, these are largely the same states identified above as having higher than average labor productivity and significant negative

\footnotetext{
${ }^{8}$ In this regard our approach differs from other applications of mixture models to - usuallypersonal income distribution data. The critical question in that literature is to identify shapes, thresholds and potentially mechanisms that define different quantiles of a distribution. For a discussion, see Section 2 of Scharfenaker \& Schneider (2019).

${ }^{9}$ Under the conventional method for calculating BIC, models with lower values are seen as more desirable. However, the mclust methodology calculates the negative of the traditional BIC, and hence the maximum BIC corresponds to the preferred model.
} 
contributions to the US payroll share over the period.

\section{[FIGURES 7 AND 8 ABOUT HERE]}

Figure 8 shows results for each of the four major business cycles. We find that the real wage exhibits a unimodal distribution throughout all cycles, albeit the distribution becomes more skewed towards the right especially in the last two cycles. In contrast, the productivity mixture appears to change over time. In the initial cycle (1979-1989), productivity is unimodal. However, in the following two cycles (19892000 and 2000-2007) productivity exhibits a bimodal mixture. The distribution of labor productivity returns to unimodal in the most recent business cycle, but with a pronounced shoulder on the right. On balance, the evidence here clearly suggests that labor productivity levels across states appear to be the result of two distinct processes: one relatively progressive, one rather stagnant.

We posit two crucial insights. First, the bimodal distribution for labor productivity renders regional dualism a distinct possibility. Such dualism implies the coexistence of regional economies with qualitatively different features that may translate in different growth performances, sources of growth, sectoral composition and distribution of income. Given the nonuniform geographical distribution of progressive activities in the US economy, this might not come as a surprise- but Figures 7 and 8 provide illustrative evidence.

Extensive evidence of dualism at the sectoral level is presented by Storm (2017), Taylor \& Ömer (2019) and Mendieta-Muñoz et al. (2019). The latter connects Baumol's analysis of dualism to the observed decline in the US payroll share. Baumol's cost disease presumes that nominal wages in progressive and stagnant sectors are determined by progressive sector labor productivity. Due to a lack of productivity growth in stagnant sectors, prices have to rise to ward off a profit squeeze. The key finding is that while the terms-of-trade of stagnant sectors have indeed risen, a pronounced and simultaneous decoupling of wages and productivity especially in progressive sectors occurred - calling into question the very heart of Baumol's mechanism. In summary, results at the sectoral level indicate that there have been strong negative contributions to the aggregate payroll share from progressive activities (i.e. manufacturing, wholesale trade, information, and finance) and positive contributions from stagnant sectors.

A similar pattern seems to arise at the regional level, which leads to the second insight. We hypothesize that the relationship between real wages and productivity in progressive vs. stagnant states differs. Evidence presented in preceding sections confirms that decoupling has not been uniform across states. Of course, decoupling per se does not require multimodal mixtures, but the pertinent question is how decoupling and dualism interact. 


\subsection{Bivariate mixtures: Dualism and decoupling}

This section considers the joint distributions of payroll shares and labor productivity across states. Before we present and discuss evidence, we briefly motivate this approach with the help of Figure 9.

\section{[FIGURE 9 ABOUT HERE]}

A state's average payroll share is shown on the horizontal axis. A move over time to the left represents a decline in the state's payroll share as its real wage falls behind labor productivity growth $(\hat{\omega}<\hat{\varepsilon})$-thus reflecting downward decoupling. Analogously, a move to the right describes upward decoupling, i.e. an increase in the payroll share as real wages grow faster (or falls less) than labor productivity. On the vertical axis, relative labor productivity is a proxy for regional differences. It is calculated as the state's labor productivity over the unweighted population average. A vertical move reflects a widening gap between the state's economic performance and the average for the US economy.

A state can belong to one of four quadrants: high payroll share and labor productivity in quadrant I; low payroll share/high productivity in quadrant II; low payroll share and labor productivity in quadrant III; and high payroll share/low productivity in quadrant IV. Below, we apply a bivariate mixture model for each of the four business cycles. Our discussion focuses on two issues. First, emphasis is placed on the scatter and its movement over time: if groups of states move towards the left across the four cycles, we observe downward decoupling. Similarly, if some states move up while others move down over time, we observe rising dualism. Second, the mixture model lends further support to dualism if significantly different distributional means are found to be separated along the vertical axis.

We now present two sets of results. Both feature the average payroll share over the relevant subperiod, and relate these to relative labor productivity levels (Figure 10) and relative labor productivity growth rates (Figure 11) 10 Following our proposed conceptual representation, all graphs are divided into quadrants by the unweighted average payroll share on the horizontal axis, and the line crossing at unity on the vertical axis representing the point where the state $j$ 's level (growth rate) of labor productivity is the same as the unweighted average labor productivity (growth rate). We label in these figures only states that have contributed more than twice the (absolute) average contribution to the change in the payroll share over the

\footnotetext{
${ }^{10}$ Relative average labor productivity is calculated as the ratio of state $i$ annual average labor productivity over the annual unweighted average labor productivity for all states. Average relative labor productivity growth is simply calculated as the ratio of state $i$ percentage change in peak-topeak labor productivity over the unweighted average of peak-to-peak change in labor productivity for all states. The analysis covers 47 states. In addition to DC, we have excluded the resourceintensive states of Alaska, Louisiana, and Wyoming which are outliers and would have distorted the analysis and data visualization significantly.
} 
entire period 11

\section{[FIGURES 10 AND 11 ABOUT HERE]}

We make three broad observations. First, the bivariate mixture model detects two distinct distributions across seven of the eight periods and cases ${ }^{12}$ Practically speaking, the algorithm finds sufficiently different features of the joint distributions of payroll share and labor productivity across states to generate distinct clusters.

Second, the distributional means differ along both vertical (productivity) and horizontal (payroll share) axis. In other words, each cycle features relatively low and high productivity and payroll share distributions. However, the location of these distributions has changed significantly over time. Crucially, the low payroll share distribution has migrated upwards towards a higher relative labor productivity, while the distribution to the right of center has moved downwards. Regional dualism is apparent in that the distance between distributions increases over time. Moreover, the distribution with relatively good productivity performance had an above average payroll share initially, but the states constituting this cluster now have below average payroll shares. Indeed, movements in the distributions are to a striking degree mirrored by movements of states across quadrants: quadrant I has emptied out over time, while the number of states in quadrant II has more than doubled, capturing the decline in the payroll shares across states.

Third, we highlight movements of particular states across quadrants and distributions over the four business cycles. We focus here on a comparison of first and last cycle. To begin, only states from quadrant IV (low labor productivity but high payroll share) have managed to move to quadrant I (high payroll share and high labor productivity) ${ }^{13}$ Furthermore, the large states of California, New York and Washington, initially in quadrant I, transitioned to quadrant II by the end of the period, driving much of the decline in the US payroll share - as seen in results from the Divisia decomposition, too.

Of particular relevance are changes within the high payroll share distribution, which are especially clear in Figure 10. In the first cycle, this distribution included most states aside of those with important primary activities, and the large state of

\footnotetext{
${ }^{11}$ The average contribution to the US payroll share between 1977 and 2017 was -0.06 percentage points. According to Table 1 the states that have contributed more than twice the absolute value of the average contribution are: New York, California, Pennsylvania, Texas, Ohio, Michigan, Illinois, Indiana, North Carolina, Georgia, Connecticut, New Jersey, and Washington on the negative side; and Minnesota, Arizona, Kentucky, Virginia, Louisiana, and Florida on the positive side of contributions. However, as explained above we exclude Louisiana from the analysis.

${ }^{12}$ The exception is Panel (b) of Figure 10, which shows average relative labor productivity levels vis-à-vis the payroll share in the cycle 1989-2000. In subsequent discussion, recall that the members of each distribution might be different.

${ }^{13}$ Between the first and the last business cycle, three (five) states have transitioned to quadrant I in Figure 10 (Figure 11). These were Colorado, Maryland and Massachusetts, and Colorado, Ohio, Oregon, Pennsylvania and Wisconsin, respectively.
} 
Texas. In the last cycle, California, New York, Washington and Connecticut, Illinois, and New Jersey had shifted left as they maintained their labor productivity rank but experienced downward decoupling. In contrast, Michigan, Ohio, Pennsylvania and Virginia remained in the distribution with low relative productivity, reinforcing the emergence of regional dualism suggested by the univariate analysis above 14

\section{Concluding remarks}

This paper investigates the decline of the US labor share by states for the period 1977-2017, and the four major business cycles contained therein. We focus on the payroll share, and further exclude public and real estate-related activities.

We conduct two exercises. First, a Divisia index decomposition provides detailed measures of the contributions of real wages, employment structure, labor productivity and relative prices across the states to the aggregate change in the labor share. These results offer further evidence that the decrease in the labor share is driven by within-unit changes, rather than reallocation effects. Specifically, it is the gap between productivity and real wage growth within states that dominates the aggregate change.

Second, univariate and bivariate mixture models indicate that the distribution of labor productivity - but not that of real wages - across the states has become increasingly dislocated. Our results furnish evidence in favor of the hypothesis that labor productivity in US states differs in a statistically significant manner. Particularly the bivariate mixture model results stand out in this regard: during the last two cycles, states with relatively high labor productivity feature relatively low payroll shares, and vice versa. In sharp contrast, in the earlier period states with high labor productivity featured high payroll shares.

Future research should investigate this pattern and the underlying mechanisms in more detail. One obvious route forward is to explore the sectoral composition of state economies in the context of this decline. Florida, California, and Michigan all differ in quite obvious ways, and sectoral variation can be exploited productively in further research. A second is to explicitly link the patterns detected in the bivariate analysis to the hypothesis of a race to the bottom. According to our results, private business in high labor productivity states pays relatively high wages, but apparently does not need to offer wage increases in accordance with labor productivity growth to attract labor. Hence, the relevant hypothesis - as forcefully argued by Taylor (2020) - is that wage suppression is the key mechanism 15

\footnotetext{
${ }^{14}$ Although not the main topic of this paper, our results are in line with a growing empirical literature which does not find support for income convergence between US states in the recent decades (Kinfemichael \& Morshed, 2019, Ganong \& Shoag, 2017, Young et al. , 2008). Moreover, Quah (1993) makes the simple yet pertinent argument that diverging bimodal cross-sectional distributions of the likes of our univariate and bivariate mixture models are inconsistent with the neoclassical model of balanced growth.

${ }^{15} \mathrm{~A}$ growing number of studies have found meaningful associations between factors, such as
} 
globalization and rate of de-unionization, and the decline in the labor share and rising income inequality both at the country and regional levels (Rada \& Kiefer 2016. Florida \& Mellander, 2016). Further, these factors can become relevant for understanding the mechanism behind potential suppression of wages relative to productivity. 


\section{References}

Ang, B.W. 2004. Decomposition analysis for policymaking in energy: Which is the preferred method? Energy Policy, 32(9), 1131 - 1139.

Autor, David, Dorn, David, Katz, Lawrence F., Patterson, Christina, \& Reenen, John Van. forthcoming. The fall of the labor share and the rise of superstar firms. Quarterly Journal of Economics.

Bhaduri, Amit, \& Skarstein, Rune. 2003. Effective demand and the terms of trade in a dual economy: a Kaldorian perspective. Cambridge Journal of Economics, $\mathbf{2 7}(4), 583-595$.

Dietzenbacher, Erik, \& Los, Bart. 1998. Structural Decomposition Techniques: Sense and Sensitivity. Economic Systems Research, 10(4), 307-324.

Diewert, W. Erwin. 2010. On the Tang and Wang Decomposition of Labour Productivity Growth into Sectoral Effects. Chap. 4, pages 67-76 of: et al, W.E. Diewert (ed), Price and productivity measurement, vol. Volume 6. Trafford Press.

Dumagan, Jesus C. 2002. Comparing the superlative Törnqvist and Fisher ideal indexes. Economics Letters, 76(2), 251 - 258.

Elsby, Mwl, Hobijn, B, \& Sahin, A. 2013. The Decline of the US Labor Share. Brookings Papers On Economic Activity, 1-63.

Florida, Richard, \& Mellander, Charlotta. 2016. The Geography of Inequality: Difference and Determinants of Wage and Income Inequality across US Metros. Regional Studies, 50(1), 79-92.

Ganong, Peter, \& Shoag, Daniel. 2017. Why has regional income convergence in the U.S. declined? Journal of Urban Economics, 102, 76 - 90.

Karabarbounis, Loukas, \& Neiman, Brent. 2014. The global decline of the labor share.(Report). Quarterly Journal of Economics, 129(1).

Kehrig, M., \& Vincent, N. 2018. The micro-level anatomy of the labor share decline. NBER Working Paper 25275.

Kinfemichael, Bisrat, \& Morshed, A.K.M. Mahbub. 2019. Convergence of labor productivity across the US states. Economic Modelling, 76, 270-280.

Lewis, Arthur W. 1954. Economic Development with Unlimited Supplies of Labour. The Manchester School.

Magrini, Stefano, Gerolimetto, Margherita, \& Duran, Hasan Engin. 2015. Regional Convergence and Aggregate Business Cycle in the United States. Regional Studies, 49(2), 251-272. 
Mendieta-Muñoz, I., Rada, C., \& von Arnim, R. 2019 (Oct.). The Decline of the US Labor Share Across Sectors. INET Working Paper 105. Institute for New Economic Thinking.

Quah, Danny. 1993. Galton's Fallacy and Tests of the Convergence Hypothesis. The Scandinavian Journal of Economics, 95(4), 427-443.

Rada, Codrina, \& Kiefer, David. 2016. Distribution-Utilization Interactions: A Race-to-the-Bottom Among Oecd Countries. Metroeconomica, 67(2), 477-498.

Rognlie, M. 2015. Deciphering the fall and rise in the net capital share: Accumulation or scarcity? Brookings Papers on Economic Activity, 2015(SPRING), $1-54$.

Scharfenaker, E., \& Schneider, M.P.A. 2019. Labor Market Segmentation and the Distribution of Income: New Evidence from Internal Census Bureau Data. University of Utah Dept. of Economics Working Paper Series, 1-39.

Scrucca, Luca, Fop, Michael, Murphy, Thomas Brendan, \& Raftery, Adrian E. 2016. mclust 5: clustering, classification and density estimation using Gaussian finite mixture models. The $R$ Journal, 8(1), 205-233.

Storm, Servaas. 2017. The New Normal: Demand, Secular Stagnation, and the Vanishing Middle Class. International Journal of Political Economy, 46(4), 169210.

Taylor, L., \& Ömer, Ö. 2019. Where do profits and jobs come from? Employment and distribution in the US economy. Review of Social Economy, 0(0), 1-20.

Taylor, Lance. 2020. Macroeconomic Inequality from Reagan to Trump: Market Power, Wage Repression, Asset Price Inflation, and Industrial Decline. Cambridge University Press.

Young, Andrew T., Higgins, Matthew J., \& Levy, Daniel. 2008. Sigma Convergence versus Beta Convergence: Evidence from U.S. County-Level Data. Journal of Money, Credit and Banking, 40(5), 1083-1093. 


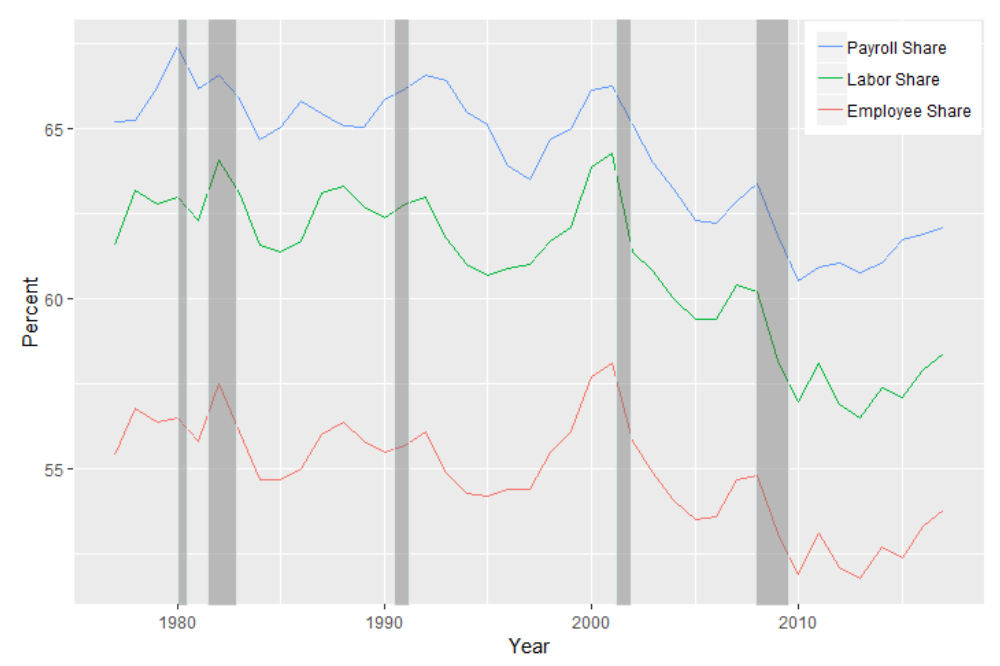

Figure 1: US aggregate payroll share (1977-2017); recessions depicted by gray bars

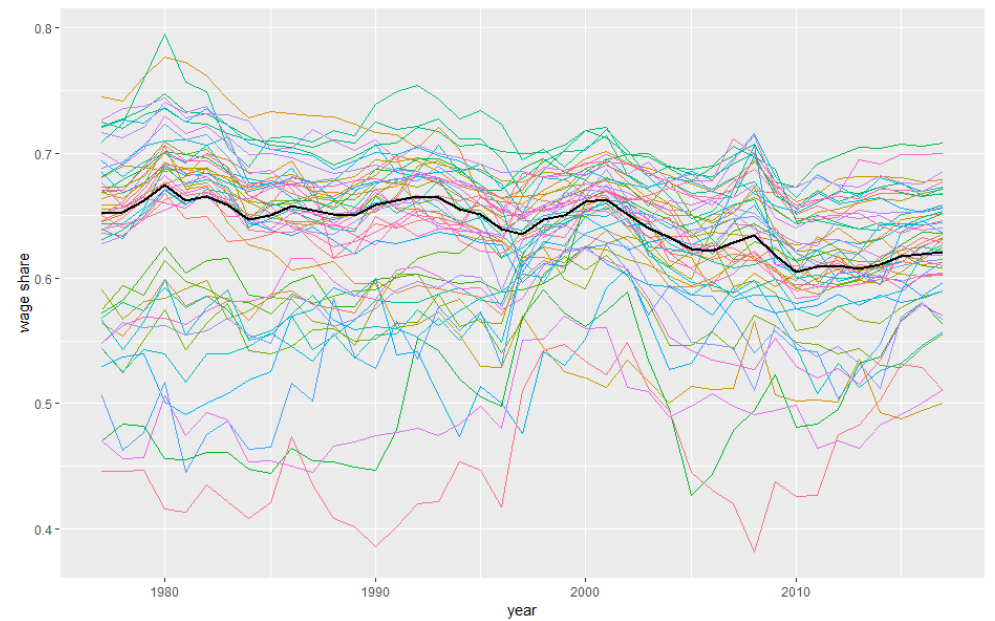

Figure 2: State payroll shares (1977-2017) 


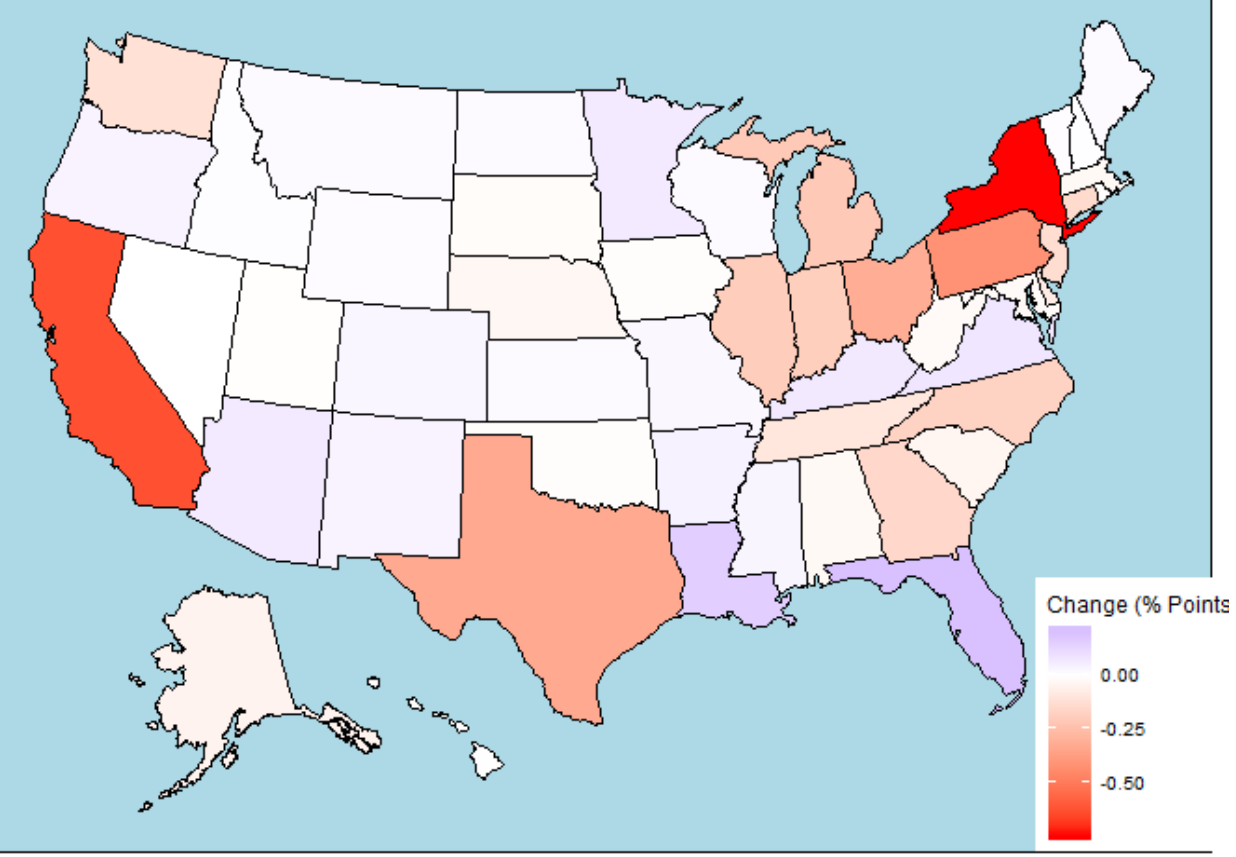

Figure 3: Aggregate contribution to national wage share change (1977-2017)
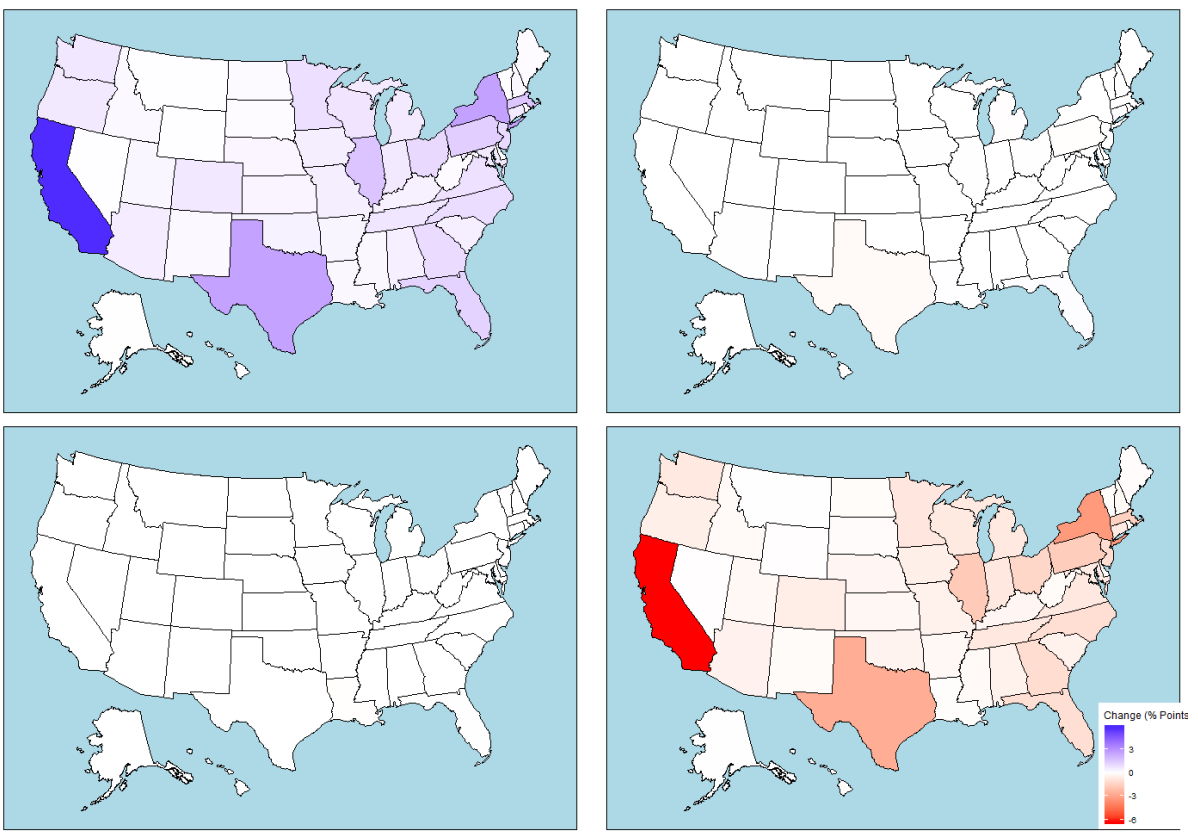

Figure 4: Contribution to national wage share change by component, (1977-2017); clockwise from top-left: compensation, structure, productivity, terms-of-trade. 

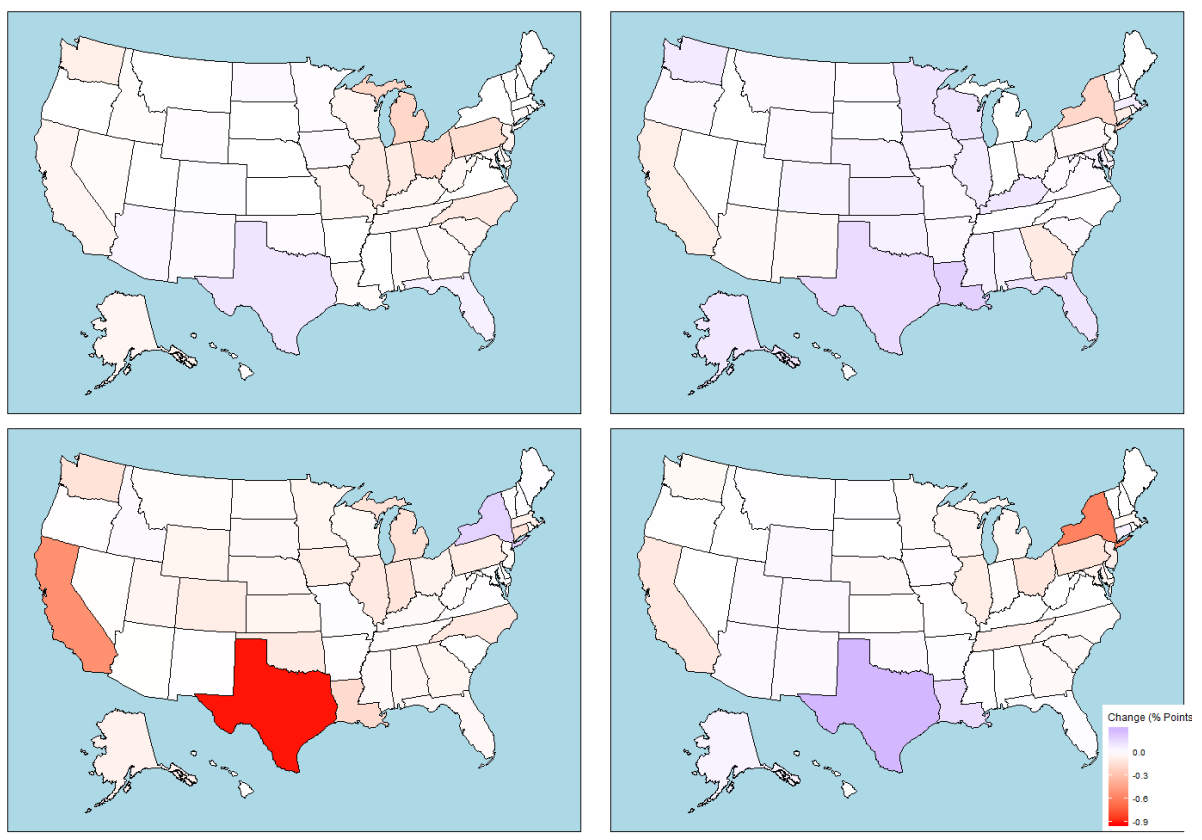

Figure 5: Total contribution to national wage share across business cycles; from top: 79-89, 89-00, 00-07, 07-17.

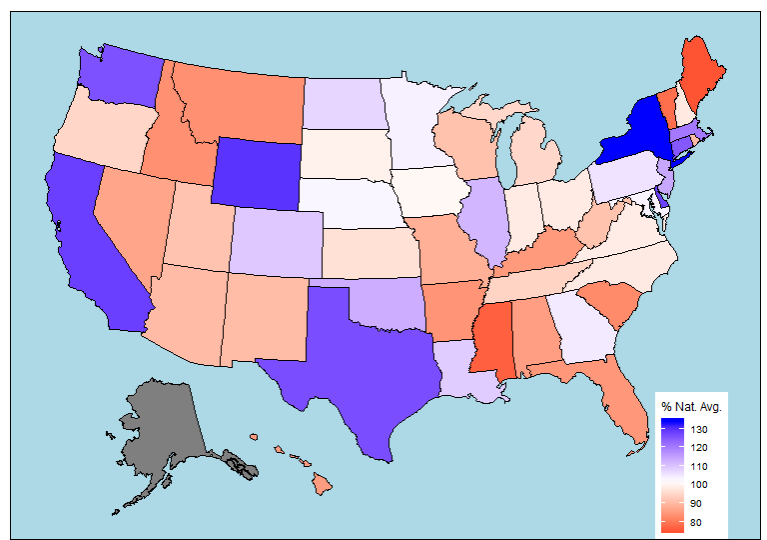

(a) Relative labor productivity

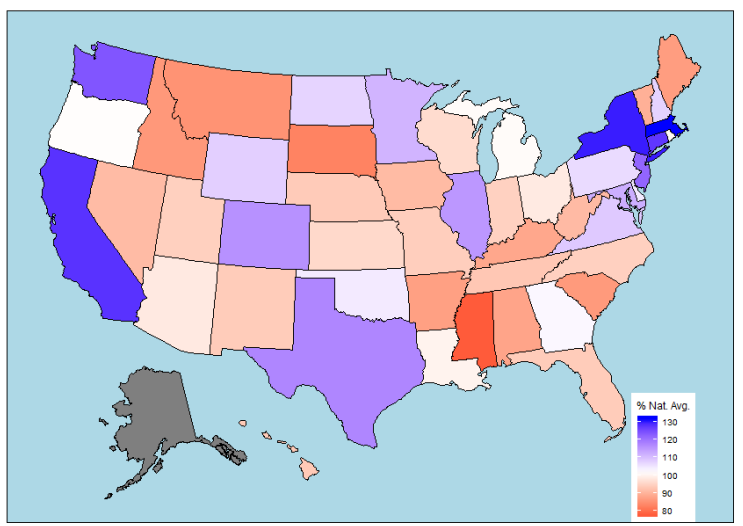

(b) Relative real wage

Figure 6: State labor productivity and real wage (2017); 2012 state chained dollars. (Excludes Alaska and DC for clarity) 

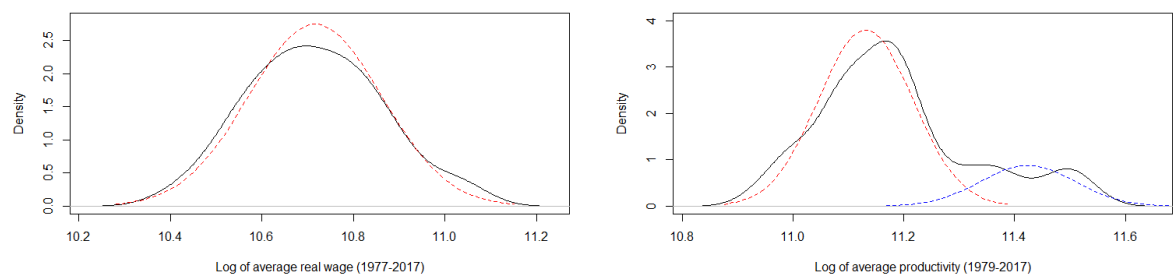

Figure 7: Result of mixture model: densities of log average annual real wage and labor productivity (2012 state chained dollars) by component for whole period. Bold lines indicate kernel density of the entire data, while dashed lines indicate distributions selected by the mixture model. Excludes Alaska and DC. 

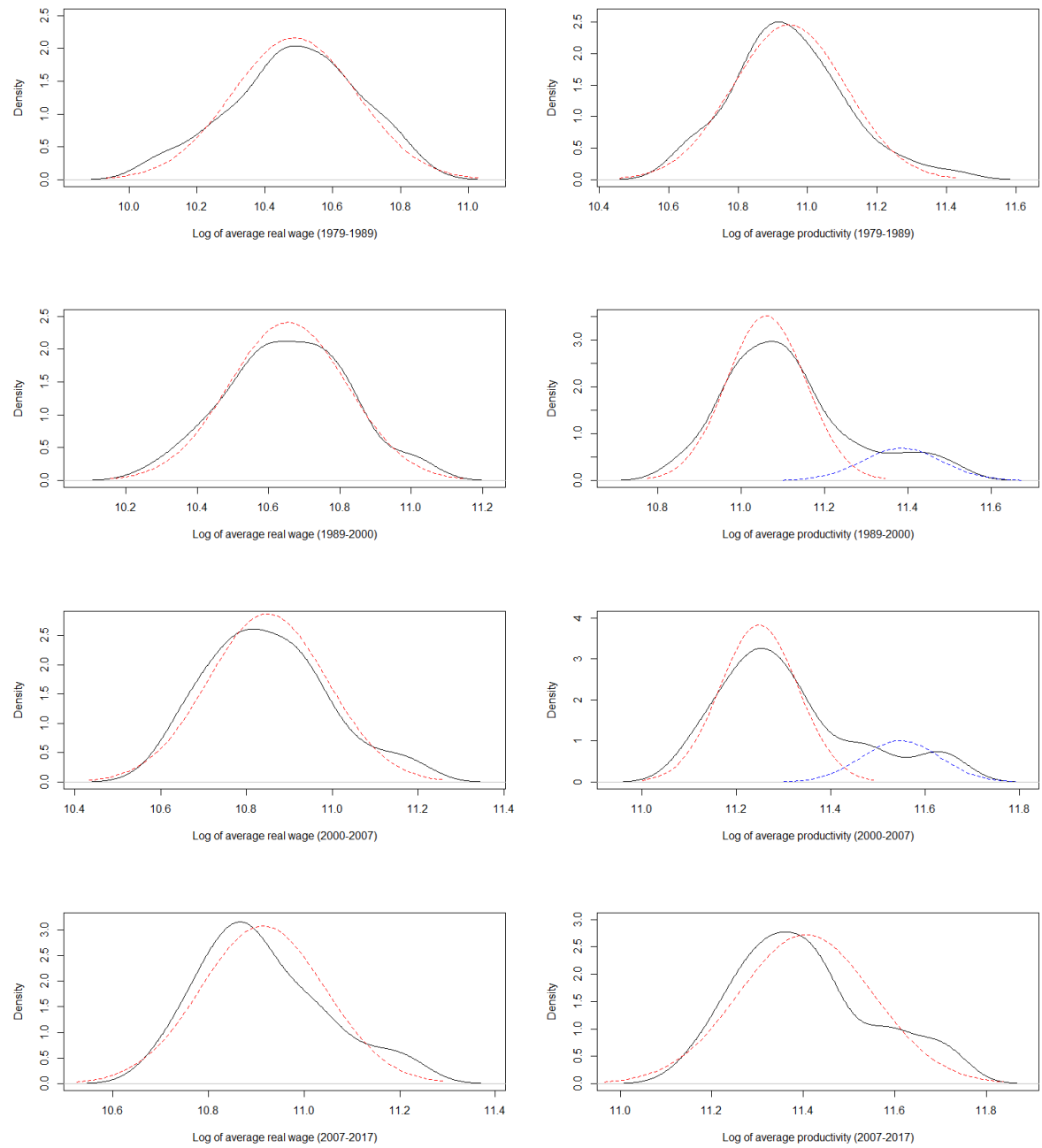

Figure 8: Result of mixture model: densities of log average annual real wage and labor productivity (2012 state chained dollars) by component over each business cycle. Bold lines indicate kernel density of the entire data, while dashed lines indicate distributions selected by the mixture model. Excludes Alaska and DC. 


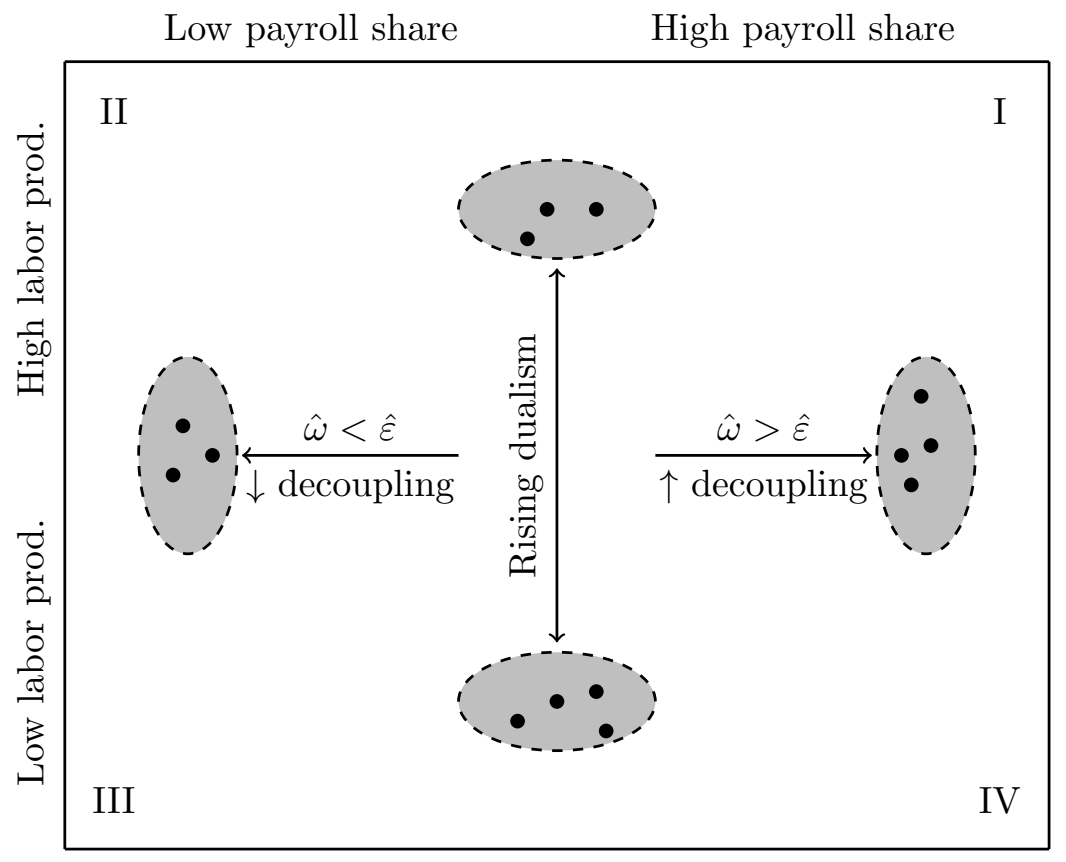

Figure 9: Decoupling and regional dualism: a conceptual framework 


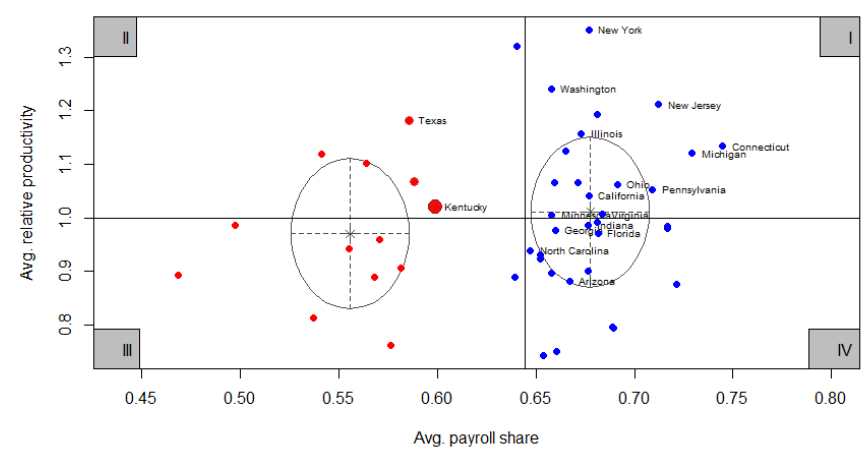

(a) 1979-1989

હ̃

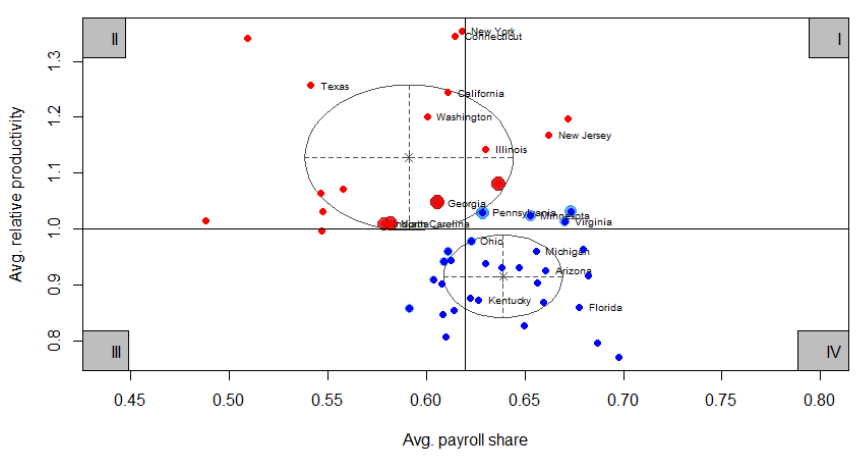

(c) $2007-2017$

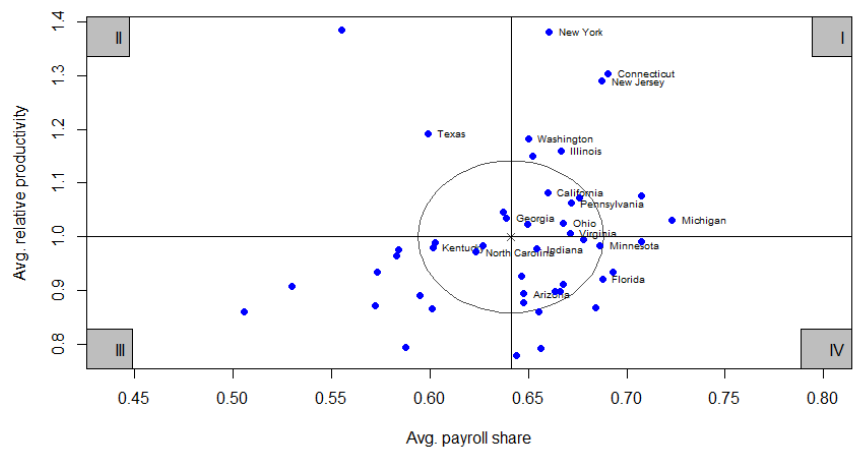

(b) $1989-2000$

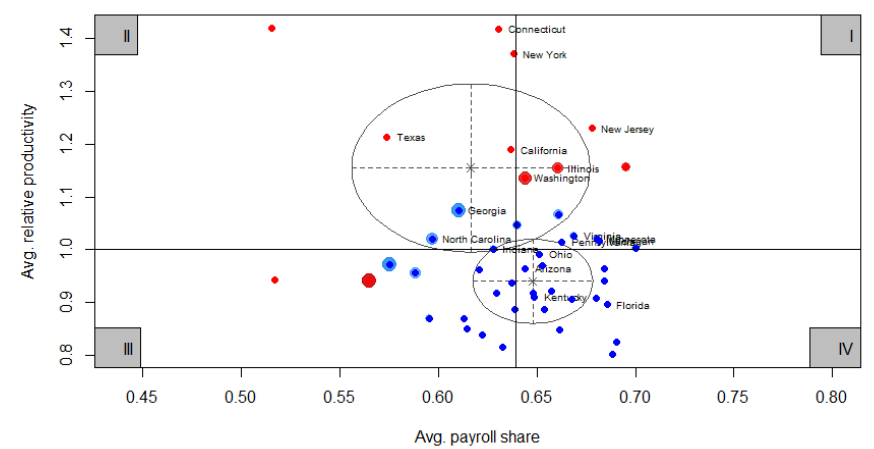

(d) $2000-2007$

Figure 10: Bivariate mixture model analysis of the payroll share and relative labor productivity across business cycles. Dot color indicates grouping based on most-likely generative distribution, dot size indicates degree of classification uncertainty. Excludes Alaska, DC, Louisiana, and Wyoming due to their outlier nature. 


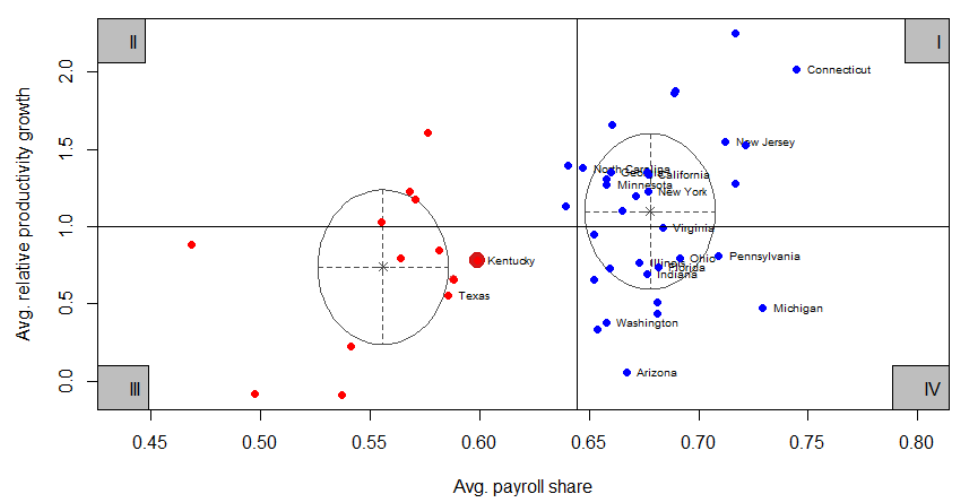

(a) 1979-1989

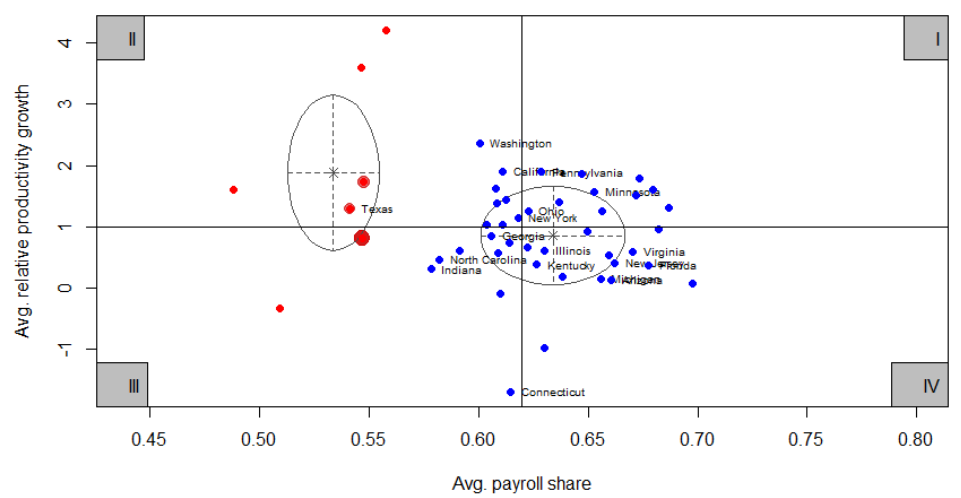

(c) $2007-2017$

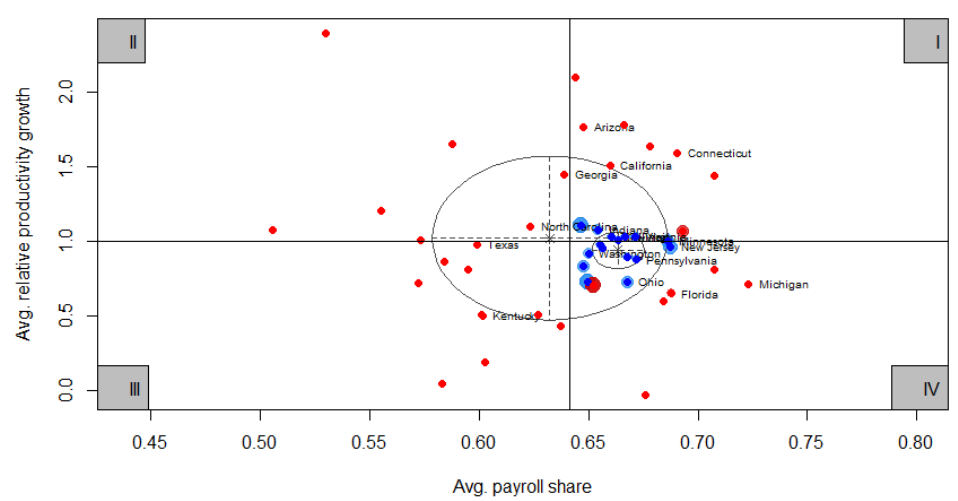

(b) $1989-2000$

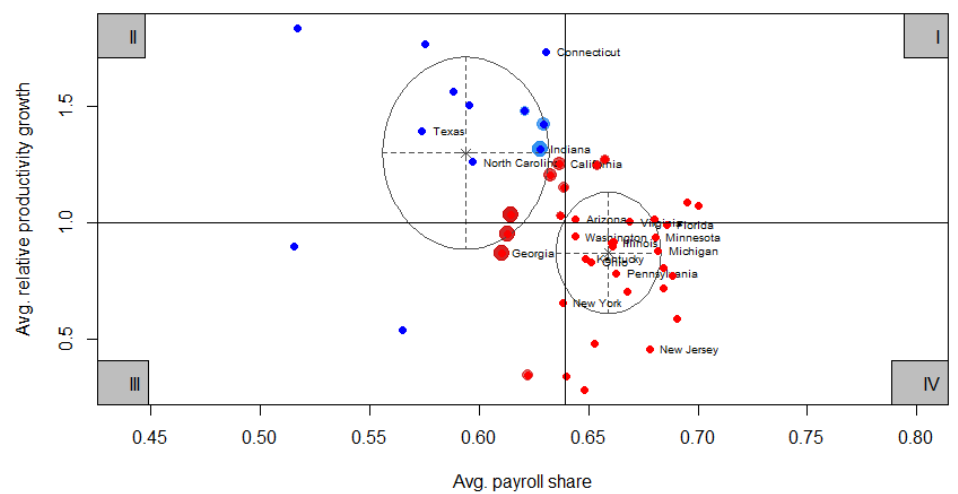

(d) $2000-2007$

Figure 11: Bivariate mixture model analysis of the payroll share and relative labor productivity growth across business cycles. Dot color indicates grouping based on most-likely generative distribution, dot size indicates degree of classification uncertainty. Excludes Alaska, DC, Louisiana, and Wyoming due to their outlier nature. 


\section{A Payroll share by states: Series definitions}

\section{Compensation}

SAGDP4S (1963-1997): Compensation is total remuneration, both monetary and in kind, payable by employers to employees in return for their work during the period. It consists of wages and salaries and of supplements to wages and salaries. Compensation is in thousands of current dollars (not adjusted for inflation). Statistics presented in thousands of dollars do not indicate more precision than statistics presented in millions of dollars. Industry detail for the years 1987-97 is based on the 1987 Standard Industrial Classification (SIC). Industry detail for the years 1963-86 is based on the 1972 SIC.

SAGDP4N (1997-2017) : Compensation is total remuneration, both monetary and in kind, payable by employers to employees in return for their work during the period. It consists of wages and salaries and of supplements to wages and salaries. Compensation is in thousands of current dollars (not adjusted for inflation). Statistics presented in thousands of dollars do not indicate more precision than statistics presented in millions of dollars. Industry detail is based on the 2012 North American Industry Classification System (NAICS).

\section{Gross Operating Surplus}

SAGDP7S (1963-1997): Gross operating surplus is in thousands of current dollars (not adjusted for inflation). Statistics presented in thousands of dollars do not indicate more precision than statistics presented in millions of dollars. Industry detail for the years 1987-97 is based on the 1987 Standard Industrial Classification (SIC). Industry detail for the years 1963-86 is based on the 1972 SIC.

SAGDP7N (1997-2017): Gross operating surplus is in thousands of current dollars (not adjusted for inflation). Statistics presented in thousands of dollars do not indicate more precision than statistics presented in millions of dollars. Industry detail is based on the 2012 North American Industry Classification System (NAICS).

\section{Employment}

SAEMP27S (1969-1996): Full-time and part-time wage and salary employment measured in number of employees. Wage and salary employment, also referred to as wage and salary jobs, measures the average annual number of full-time and parttime jobs in each area by place of work. All jobs for which wages and salaries are paid are counted. Although compensation paid to jurors, expert legal witnesses, prisoners, and justices of the peace (for marriage fees), is counted in wages and salaries, these activities are not counted as jobs in wage and salary employment. Corporate directorships are counted as self-employment. Industry detail for the years 1987-96 is based on the 1987 Standard Industrial Classification (SIC). Industry detail for the years 1969-86 is based on the 1972 SIC. 
CAEMP27S (1997-2017): Full-time and part-time wage and salary employment measured in number of employees. Wage and salary employment, also referred to as wage and salary jobs, measures the average annual number of full-time and parttime jobs in each area by place of work. All jobs for which wages and salaries are paid are counted. Although compensation paid to jurors, expert legal witnesses, prisoners, and justices of the peace (for marriage fees), is counted in wages and salaries, these activities are not counted as jobs in wage and salary employment. Corporate directorships are counted as self-employment. Industry detail is based on the 2012 North American Industry Classification System (NAICS).

\section{Value Added}

SAGDP9S (1977-1997): Real GDP is in millions of chained 1997 dollars. Industry detail for the years 1987-97 is based on the 1987 Standard Industrial Classification (SIC). Industry detail for the years 1963-86 is based on the 1972 SIC. Calculations are performed on unrounded data.

SAGDP9S (1997-2017): Real GDP is in millions of chained 2012 dollars. Industry detail is based on the 2012 North American Industry Classification System (NAICS). Calculations are performed on unrounded data. Chained (2012) dollar series are calculated as the product of the chain-type quantity index and the 2012 current-dollar value of the corresponding series, divided by 100. Because the formula for the chain-type quantity indexes uses weights of more than one period, the corresponding chained-dollar estimates are usually not additive. The difference between the United States and sum-of-states reflects federal military and civilian activity located overseas, as well as the differences in source data used to estimate GDP by industry and the expenditures measure of real GDP.

SAGDP2S (1963-1997): Gross Domestic Product (GDP) is in millions of current dollars. Industry detail for the years $1987-97$ is based on the 1987 Standard Industrial Classification (SIC). Industry detail for the years 1963-86 is based on the 1972 SIC. Calculations are performed on unrounded data.

SAGDP2N (1997-2017): Gross Domestic Product (GDP) is in millions of current dollars (not adjusted for inflation). Industry detail is based on the 2012 North American Industry Classification System (NAICS). Calculations are performed on unrounded data.

\section{B Divisia index decomposition}

The wage share in an economy is generally defined as the ratio of nominal values of the wage bill and value added. If there are $j$ regions or states the payroll share can be written as the ratio of the sum of state level nominal wage bill and the sum of 
state level nominal value added:

$$
\psi=\frac{\sum_{j=1}^{n} w_{j} L_{j}}{\sum_{j=1}^{n} P_{j} X_{j}}
$$

where $w_{j}, L_{j}, P_{j}, X_{j}$ are the nominal wage, employment, price level and quantity of output at the state level. Straightforward algebraic manipulation allows us to rewrite aggregate payroll share as follows:

$$
\psi=\frac{\sum_{j=1}^{n} p_{j} \omega_{j} \lambda_{j}}{\sum_{j=1}^{n} p_{j} \varepsilon_{j} \lambda_{j}}
$$

Multiplying (7) by $P L / P L$ the general price level and aggregate employment we get that:

$$
\psi=\frac{\sum_{j=1}^{n} w_{j} L_{j}}{P L} \frac{P L}{\sum_{j=1}^{n} P_{j} X_{j}}=\omega / \varepsilon
$$

where $\omega, \varepsilon$ are the average real wage and productivity which can be disaggregated according to:

$$
\begin{gathered}
\omega=\frac{\sum_{j=1}^{n} w_{j} L_{j}}{P L}=\sum_{j=1}^{n} \frac{P_{j} w_{j} L_{j}}{P P_{j} L}=\sum_{j=1}^{n} p_{j} \omega_{j} \lambda_{j} \\
\varepsilon=\frac{\sum_{j=1}^{n} P_{j} X_{j}}{P L}=\sum_{j=1}^{n} \frac{P_{j} X_{j}}{P L_{j}} \frac{L_{j}}{L}=\sum_{j=1}^{n} p_{j} \varepsilon_{j} \lambda_{j}
\end{gathered}
$$

where $\omega_{j}, \varepsilon_{j}, \lambda_{j}, p_{j}$ indicate real compensation or the nominal wage deflated by the state price level $P_{j}$, labor productivity, employment share and terms-of-trade at the state level. Using (10) and (11) the aggregate wage share can be written as:

$$
\psi=\frac{\sum_{j=1}^{n} p_{j} \omega_{j} \lambda_{j}}{\sum_{j=1}^{n} p_{j} \varepsilon_{j} \lambda_{j}}
$$


The overall wage share can now be decomposed into several contributing factors. Changes in the state real wage and labor productivity amount to shift effects; changes in the regional structure of the economy as measured by the state employment shares are perceived as structural or share effects while changes in the terms-of trade are market structure effects.

Assuming that all variables are continuous, differentiating (12) with respect to time, $t$, and dividing both sides by $\psi$ yields:

$d \ln (\psi) / d t=\sum \phi_{j}\left[d \ln \left(p_{j}\right) / d t+d \ln \left(\omega_{j}\right) / d t+d \ln \left(\lambda_{j}\right) / d t\right]-\sum \theta_{j}\left[d \ln \left(p_{j}\right) / d t+d \ln \left(\varepsilon_{j}\right) / d t+d \ln \left(\lambda_{j}\right) / d t\right]$

The weights $\phi_{j}$ and $\theta_{j}$ are the nominal share of state $j$ wage compensation in total wage compensation and the state $j$ share in total value added. Integrating equation (13) over the interval $[0, t]$ gives the Divisia decompositions of the growth rate of the economy-wide wage share:

$$
\begin{aligned}
\ln \frac{\psi_{t}}{\psi_{t-n}} & =\int_{t-n}^{t} \sum \phi_{j}\left[d \ln \left(p_{j}\right) / d t\right]+\int_{t-n}^{t} \sum \phi_{j}\left[d \ln \left(\omega_{j}\right) / d t\right]+\int_{t-n}^{t} \sum \phi_{j}\left[d \ln \left(\lambda_{j}\right) / d t\right] \\
& -\int_{t-n}^{t} \sum \theta_{j}\left[d \ln \left(p_{j}\right) / d t\right]-\int_{t-n}^{t} \sum \theta_{j}\left[d \ln \left(\varepsilon_{j}\right) / d t\right]-\int_{t-n}^{t} \sum \theta_{j}\left[d \ln \left(\lambda_{j}\right) / d t\right]
\end{aligned}
$$

Applying the exponential to equation (14) we get:

$$
D_{\text {tot }}=D_{\text {price }} D_{\text {comp }} D_{\text {str }} D_{\text {tech }}^{-1}
$$

where the terms are:

$$
\begin{aligned}
D_{\text {comp }} & =\exp \left[\int_{t-n}^{t} \sum \phi_{j}\left[d \ln \left(\omega_{j}\right) / d t\right]\right. \\
D_{\text {str }} & =\exp \left[\int_{t-n}^{t} \sum\left(\phi_{j}-\theta_{j}\right)\left[d \ln \left(\lambda_{j}\right) / d t\right]\right. \\
D_{\text {price }} & =\exp \left[\int_{t-n}^{t} \sum\left(\phi_{j}-\theta_{j}\right)\left[d \ln \left(p_{j}\right) / d t\right]\right. \\
D_{\text {tech }} & =\exp \left[\int_{t-n}^{t} \sum \theta_{j}\left[d \ln \left(\varepsilon_{j}\right) / d t\right]\right.
\end{aligned}
$$

To match the discrete format of the data we can write the components of the decomposition in discrete terms:

$$
\begin{aligned}
D_{\text {comp }} & =\exp \left[\sum\left(\phi_{j, t}+\phi_{j, t-n}\right) / 2 \ln \left(\omega_{j, t} / \omega_{j, t-n}\right)\right] \\
D_{\text {str }} & =\exp \left[\sum\left[\left(\phi_{j, t}+\phi_{j, t-n}\right) / 2-\left(\theta_{j, t}+\theta_{j, t-n}\right) / 2\right] \ln \left(\lambda_{j, t} / \lambda_{j, t-n}\right)\right] \\
D_{\text {price }} & =\exp \left[\sum\left[\left(\phi_{j, t}+\phi_{j, t-n}\right) / 2-\left(\theta_{j, t}+\theta_{j, t-n}\right) / 2\right] \ln \left(p_{j, t} / p_{j, t-n}\right)\right] \\
D_{\text {tech }} & =\exp \left[\sum\left(\theta_{j, t}+\theta_{j, t-n}\right) / 2 \ln \left(\varepsilon_{j, t} / \varepsilon_{j, t-n}\right)\right]
\end{aligned}
$$




\section{Divisia decomposition results}

\begin{tabular}{|c|c|c|c|c|c|c|}
\hline & State & Comp & Str & Tech & Price & Total \\
\hline 1 & Alabama & 0.42 & -0.00 & -0.44 & -0.00 & -0.02 \\
\hline 2 & Alaska & -0.02 & -0.00 & -0.02 & 0.00 & -0.05 \\
\hline 3 & Arizona & 0.47 & 0.02 & -0.42 & -0.00 & 0.07 \\
\hline 4 & Arkansas & 0.27 & 0.00 & -0.24 & 0.00 & 0.04 \\
\hline 5 & California & 5.70 & 0.00 & -6.33 & -0.00 & -0.62 \\
\hline 6 & Colorado & 0.62 & 0.01 & -0.59 & -0.00 & 0.03 \\
\hline 7 & Connecticut & 0.55 & -0.02 & -0.68 & 0.01 & -0.14 \\
\hline 8 & Delaware & 0.06 & -0.00 & -0.13 & -0.00 & -0.07 \\
\hline 9 & District of Columbia & 0.11 & -0.00 & -0.09 & 0.01 & 0.03 \\
\hline 10 & Florida & 1.18 & 0.08 & -1.07 & 0.01 & 0.20 \\
\hline 11 & Georgia & 0.97 & -0.01 & -1.12 & -0.00 & -0.15 \\
\hline 12 & Hawaii & 0.06 & 0.00 & -0.06 & 0.00 & 0.00 \\
\hline 13 & Idaho & 0.18 & -0.00 & -0.17 & 0.00 & 0.01 \\
\hline 14 & Illinois & 1.60 & -0.03 & -1.77 & 0.00 & -0.20 \\
\hline 15 & Indiana & 0.59 & 0.00 & -0.78 & 0.00 & -0.19 \\
\hline 16 & Iowa & 0.47 & 0.02 & -0.53 & 0.03 & -0.01 \\
\hline 17 & Kansas & 0.28 & 0.00 & -0.27 & 0.00 & 0.02 \\
\hline 18 & Kentucky & 0.36 & 0.00 & -0.30 & 0.00 & 0.07 \\
\hline 19 & Louisiana & 0.22 & 0.05 & -0.08 & -0.04 & 0.16 \\
\hline 20 & Maine & 0.11 & -0.00 & -0.09 & 0.00 & 0.02 \\
\hline 21 & Maryland & 0.60 & 0.00 & -0.63 & 0.01 & -0.02 \\
\hline 22 & Massachusetts & 1.53 & -0.02 & -1.52 & -0.00 & -0.02 \\
\hline 23 & Michigan & 0.57 & -0.05 & -0.73 & 0.00 & -0.21 \\
\hline 24 & Minnesota & 0.85 & 0.00 & -0.79 & -0.00 & 0.06 \\
\hline 25 & Mississippi & 0.22 & 0.01 & -0.20 & 0.00 & 0.03 \\
\hline 26 & Missouri & 0.46 & -0.00 & -0.43 & 0.00 & 0.03 \\
\hline 27 & Montana & 0.06 & -0.00 & -0.04 & 0.00 & 0.02 \\
\hline 28 & Nebraska & 0.26 & 0.00 & -0.30 & 0.01 & -0.03 \\
\hline 29 & Nevada & 0.04 & 0.01 & -0.06 & 0.00 & -0.00 \\
\hline 30 & New Hampshire & 0.22 & 0.00 & -0.21 & -0.00 & 0.01 \\
\hline 31 & New Jersey & 1.01 & -0.03 & -1.12 & 0.02 & -0.13 \\
\hline 32 & New Mexico & 0.18 & -0.00 & -0.15 & 0.01 & 0.04 \\
\hline 33 & New York & 2.56 & -0.01 & -3.30 & 0.01 & -0.74 \\
\hline 34 & North Carolina & 0.90 & -0.00 & -1.07 & -0.00 & -0.17 \\
\hline 35 & North Dakota & 0.13 & -0.00 & -0.11 & 0.00 & 0.02 \\
\hline 36 & Ohio & 1.03 & -0.02 & -1.32 & -0.00 & -0.31 \\
\hline 37 & Oklahoma & 0.36 & 0.01 & -0.39 & 0.01 & -0.01 \\
\hline 38 & Oregon & 0.58 & 0.00 & -0.54 & -0.00 & 0.04 \\
\hline 39 & Pennsylvania & 1.29 & -0.04 & -1.67 & 0.01 & -0.41 \\
\hline 40 & Rhode Island & 0.13 & -0.01 & -0.13 & 0.00 & -0.01 \\
\hline 41 & South Carolina & 0.43 & 0.00 & -0.47 & -0.00 & -0.04 \\
\hline 42 & South Dakota & 0.11 & -0.00 & -0.13 & 0.01 & -0.01 \\
\hline 43 & Tennessee & 0.68 & -0.00 & -0.78 & 0.00 & -0.10 \\
\hline 44 & Texas & 2.54 & -0.19 & -2.68 & 0.01 & -0.33 \\
\hline 45 & Utah & 0.23 & 0.00 & -0.23 & -0.00 & -0.00 \\
\hline 46 & Vermont & 0.08 & -0.00 & -0.07 & -0.00 & 0.01 \\
\hline 47 & Virginia & 0.81 & 0.01 & -0.75 & 0.01 & 0.08 \\
\hline 48 & Washington & 0.63 & -0.01 & -0.74 & -0.00 & -0.12 \\
\hline 49 & West Virginia & 0.11 & 0.00 & -0.13 & 0.00 & -0.02 \\
\hline 50 & Wisconsin & 0.72 & -0.00 & -0.69 & -0.00 & 0.02 \\
\hline \multirow[t]{2}{*}{51} & Wyoming & 0.06 & 0.01 & -0.06 & 0.01 & 0.01 \\
\hline & Total & 33.59 & -0.22 & -36.62 & 0.12 & -3.13 \\
\hline
\end{tabular}

Table 1: State contributions in percentage points, $77-17$ 


\begin{tabular}{|c|c|c|c|c|c|c|}
\hline & State & Comp & Str & Tech & Price & Total \\
\hline 1 & Alabama & 0.11 & 0.00 & -0.14 & 0.00 & -0.02 \\
\hline 2 & Alaska & 0.01 & -0.02 & -0.05 & 0.02 & -0.04 \\
\hline 3 & Arizona & 0.04 & 0.00 & -0.01 & 0.00 & 0.03 \\
\hline 4 & Arkansas & 0.05 & 0.00 & -0.06 & 0.00 & -0.01 \\
\hline 5 & California & 1.48 & 0.01 & -1.54 & 0.00 & -0.04 \\
\hline 6 & Colorado & 0.08 & 0.00 & -0.06 & 0.00 & 0.01 \\
\hline 7 & Connecticut & 0.27 & -0.00 & -0.30 & 0.01 & -0.02 \\
\hline 8 & Delaware & 0.02 & -0.00 & -0.05 & -0.00 & -0.03 \\
\hline 9 & District of Columbia & 0.02 & 0.00 & -0.00 & 0.01 & 0.03 \\
\hline 10 & Florida & 0.30 & 0.02 & -0.27 & 0.00 & 0.05 \\
\hline 11 & Georgia & 0.26 & 0.00 & -0.29 & 0.00 & -0.03 \\
\hline 12 & Hawaii & 0.03 & 0.00 & -0.04 & 0.00 & -0.01 \\
\hline 13 & Idaho & 0.03 & 0.00 & -0.05 & 0.00 & -0.01 \\
\hline 14 & Illinois & 0.33 & -0.01 & -0.42 & -0.00 & -0.10 \\
\hline 15 & Indiana & 0.07 & -0.00 & -0.16 & -0.00 & -0.10 \\
\hline 16 & Iowa & 0.10 & 0.02 & -0.12 & 0.02 & 0.02 \\
\hline 17 & Kansas & 0.06 & 0.01 & -0.07 & 0.00 & 0.01 \\
\hline 18 & Kentucky & 0.06 & 0.00 & -0.10 & 0.01 & -0.04 \\
\hline 19 & Louisiana & 0.08 & 0.08 & -0.20 & 0.03 & -0.02 \\
\hline 20 & Maine & 0.04 & 0.00 & -0.05 & 0.00 & -0.00 \\
\hline 21 & Maryland & 0.15 & 0.01 & -0.20 & 0.00 & -0.03 \\
\hline 22 & Massachusetts & 0.55 & 0.00 & -0.56 & 0.00 & -0.00 \\
\hline 23 & Michigan & 0.03 & -0.03 & -0.19 & 0.00 & -0.19 \\
\hline 24 & Minnesota & 0.24 & 0.00 & -0.23 & 0.00 & 0.01 \\
\hline 25 & Mississippi & 0.07 & 0.01 & -0.09 & 0.00 & -0.01 \\
\hline 26 & Missouri & 0.11 & 0.00 & -0.15 & -0.00 & -0.04 \\
\hline 27 & Montana & 0.00 & 0.01 & -0.01 & 0.00 & 0.01 \\
\hline 28 & Nebraska & 0.06 & 0.00 & -0.07 & 0.01 & -0.00 \\
\hline 29 & Nevada & -0.00 & 0.00 & -0.02 & 0.00 & -0.02 \\
\hline 30 & New Hampshire & 0.07 & 0.00 & -0.07 & -0.00 & 0.01 \\
\hline 31 & New Jersey & 0.45 & 0.00 & -0.51 & 0.01 & -0.05 \\
\hline 32 & New Mexico & 0.02 & -0.00 & 0.00 & 0.00 & 0.02 \\
\hline 33 & New York & 1.00 & -0.01 & -1.00 & 0.01 & -0.00 \\
\hline 34 & North Carolina & 0.22 & -0.00 & -0.31 & -0.00 & -0.10 \\
\hline 35 & North Dakota & 0.01 & 0.01 & 0.00 & 0.00 & 0.02 \\
\hline 36 & Ohio & 0.22 & -0.02 & -0.37 & -0.00 & -0.17 \\
\hline 37 & Oklahoma & 0.08 & 0.01 & -0.09 & 0.01 & 0.02 \\
\hline 38 & Oregon & 0.03 & 0.00 & -0.04 & 0.00 & -0.00 \\
\hline 39 & Pennsylvania & 0.25 & -0.02 & -0.39 & 0.00 & -0.16 \\
\hline 40 & Rhode Island & 0.04 & -0.00 & -0.05 & 0.00 & -0.01 \\
\hline 41 & South Carolina & 0.13 & 0.00 & -0.18 & -0.00 & -0.05 \\
\hline 42 & South Dakota & 0.02 & 0.00 & -0.02 & 0.01 & 0.01 \\
\hline 43 & Tennessee & 0.19 & 0.00 & -0.21 & -0.00 & -0.03 \\
\hline 44 & Texas & 0.47 & 0.01 & -0.39 & 0.01 & 0.10 \\
\hline 45 & Utah & 0.04 & -0.00 & -0.03 & 0.00 & 0.00 \\
\hline 46 & Vermont & 0.02 & -0.00 & -0.03 & 0.00 & -0.01 \\
\hline 47 & Virginia & 0.19 & 0.01 & -0.20 & 0.00 & -0.00 \\
\hline 48 & Washington & -0.01 & -0.00 & -0.07 & -0.00 & -0.08 \\
\hline 49 & West Virginia & 0.03 & 0.00 & -0.07 & 0.00 & -0.04 \\
\hline 50 & Wisconsin & 0.14 & 0.00 & -0.19 & 0.00 & -0.05 \\
\hline \multirow[t]{2}{*}{51} & Wyoming & 0.01 & 0.02 & -0.03 & 0.01 & 0.01 \\
\hline & Total & 8.27 & 0.14 & -9.74 & 0.18 & -1.15 \\
\hline
\end{tabular}

Table 2: State contributions in percentage $92^{\text {ints, }}$ 79-89 


\begin{tabular}{|c|c|c|c|c|c|c|}
\hline & State & Comp & Str & Tech & Price & Total \\
\hline 1 & Alabama & 0.19 & 0.00 & -0.15 & 0.00 & 0.04 \\
\hline 2 & Alaska & 0.00 & -0.00 & 0.09 & 0.00 & 0.10 \\
\hline 3 & Arizona & 0.30 & 0.00 & -0.32 & -0.00 & -0.02 \\
\hline 4 & Arkansas & 0.12 & -0.00 & -0.09 & 0.00 & 0.03 \\
\hline 5 & California & 2.67 & -0.00 & -2.74 & -0.00 & -0.08 \\
\hline 6 & Colorado & 0.36 & 0.01 & -0.33 & -0.00 & 0.04 \\
\hline 7 & Connecticut & 0.30 & -0.01 & -0.38 & 0.00 & -0.09 \\
\hline 8 & Delaware & 0.03 & 0.00 & -0.07 & -0.00 & -0.04 \\
\hline 9 & District of Columbia & 0.03 & -0.01 & -0.03 & 0.01 & 0.00 \\
\hline 10 & Florida & 0.51 & 0.02 & -0.43 & 0.00 & 0.10 \\
\hline 11 & Georgia & 0.47 & -0.01 & -0.56 & -0.00 & -0.10 \\
\hline 12 & Hawaii & 0.01 & -0.00 & 0.00 & 0.00 & 0.01 \\
\hline 13 & Idaho & 0.08 & -0.01 & -0.08 & 0.01 & 0.00 \\
\hline 14 & Illinois & 0.84 & -0.00 & -0.76 & -0.00 & 0.08 \\
\hline 15 & Indiana & 0.33 & -0.00 & -0.34 & 0.00 & -0.00 \\
\hline 16 & Iowa & 0.19 & -0.00 & -0.15 & 0.01 & 0.05 \\
\hline 17 & Kansas & 0.14 & -0.00 & -0.07 & 0.00 & 0.07 \\
\hline 18 & Kentucky & 0.19 & -0.00 & -0.09 & 0.00 & 0.10 \\
\hline 19 & Louisiana & 0.13 & -0.00 & 0.06 & 0.01 & 0.19 \\
\hline 20 & Maine & 0.04 & -0.00 & -0.03 & 0.00 & 0.00 \\
\hline 21 & Maryland & 0.26 & -0.01 & -0.21 & 0.00 & 0.05 \\
\hline 22 & Massachusetts & 0.69 & -0.02 & -0.61 & 0.00 & 0.07 \\
\hline 23 & Michigan & 0.39 & -0.00 & -0.39 & 0.01 & -0.00 \\
\hline 24 & Minnesota & 0.38 & 0.00 & -0.28 & -0.00 & 0.10 \\
\hline 25 & Mississippi & 0.10 & -0.00 & -0.05 & 0.00 & 0.05 \\
\hline 26 & Missouri & 0.24 & 0.00 & -0.22 & -0.00 & 0.03 \\
\hline 27 & Montana & 0.02 & -0.00 & -0.00 & 0.00 & 0.02 \\
\hline 28 & Nebraska & 0.12 & -0.00 & -0.08 & 0.00 & 0.05 \\
\hline 29 & Nevada & 0.07 & -0.00 & -0.07 & -0.00 & -0.00 \\
\hline 30 & New Hampshire & 0.11 & -0.00 & -0.11 & -0.00 & 0.00 \\
\hline 31 & New Jersey & 0.52 & -0.02 & -0.52 & 0.01 & -0.01 \\
\hline 32 & New Mexico & 0.10 & -0.00 & -0.14 & 0.01 & -0.03 \\
\hline 33 & New York & 1.09 & -0.01 & -1.27 & 0.00 & -0.19 \\
\hline 34 & North Carolina & 0.42 & -0.00 & -0.43 & -0.00 & -0.01 \\
\hline 35 & North Dakota & 0.03 & -0.00 & -0.02 & 0.00 & 0.01 \\
\hline 36 & Ohio & 0.44 & -0.00 & -0.46 & 0.00 & -0.02 \\
\hline 37 & Oklahoma & 0.09 & -0.00 & -0.03 & 0.00 & 0.06 \\
\hline 38 & Oregon & 0.32 & -0.00 & -0.30 & 0.00 & 0.02 \\
\hline 39 & Pennsylvania & 0.54 & -0.01 & -0.57 & 0.00 & -0.03 \\
\hline 40 & Rhode Island & 0.05 & -0.00 & -0.05 & 0.00 & -0.01 \\
\hline 41 & South Carolina & 0.18 & 0.00 & -0.16 & -0.00 & 0.02 \\
\hline 42 & South Dakota & 0.05 & -0.00 & -0.04 & 0.01 & 0.01 \\
\hline 43 & Tennessee & 0.29 & -0.00 & -0.29 & 0.00 & 0.01 \\
\hline 44 & Texas & 1.19 & -0.05 & -1.01 & 0.01 & 0.14 \\
\hline 45 & Utah & 0.09 & 0.00 & -0.09 & -0.00 & 0.01 \\
\hline 46 & Vermont & 0.04 & -0.00 & -0.03 & -0.00 & 0.01 \\
\hline 47 & Virginia & 0.37 & 0.00 & -0.36 & 0.00 & 0.02 \\
\hline 48 & Washington & 0.36 & -0.00 & -0.28 & -0.00 & 0.08 \\
\hline 49 & West Virginia & 0.05 & 0.00 & -0.03 & 0.00 & 0.02 \\
\hline 50 & Wisconsin & 0.35 & 0.00 & -0.25 & -0.00 & 0.10 \\
\hline \multirow[t]{2}{*}{51} & Wyoming & 0.03 & -0.00 & -0.01 & 0.01 & 0.03 \\
\hline & Total & 15.94 & -0.16 & -14.80 & 0.10 & 1.08 \\
\hline
\end{tabular}

Table 3: State contributions in percentage §9ints, 89-00 


\begin{tabular}{|c|c|c|c|c|c|c|}
\hline & State & Comp & Str & Tech & Price & Total \\
\hline 1 & Alabama & 0.07 & 0.00 & -0.11 & 0.00 & -0.04 \\
\hline 2 & Alaska & -0.01 & -0.01 & -0.03 & -0.01 & -0.06 \\
\hline 3 & Arizona & 0.14 & 0.00 & -0.14 & -0.00 & -0.00 \\
\hline 4 & Arkansas & 0.05 & 0.00 & -0.06 & -0.00 & -0.01 \\
\hline 5 & California & 0.86 & 0.00 & -1.40 & 0.00 & -0.53 \\
\hline 6 & Colorado & 0.05 & 0.00 & -0.13 & 0.00 & -0.09 \\
\hline 7 & Connecticut & 0.11 & 0.00 & -0.24 & 0.00 & -0.14 \\
\hline 8 & Delaware & 0.02 & 0.00 & -0.03 & -0.00 & -0.01 \\
\hline 9 & District of Columbia & 0.04 & 0.00 & -0.05 & 0.00 & -0.01 \\
\hline 10 & Florida & 0.35 & 0.02 & -0.40 & 0.00 & -0.03 \\
\hline 11 & Georgia & 0.18 & 0.00 & -0.23 & 0.00 & -0.05 \\
\hline 12 & Hawaii & 0.01 & 0.00 & -0.02 & 0.00 & -0.01 \\
\hline 13 & Idaho & 0.03 & -0.00 & -0.01 & 0.00 & 0.02 \\
\hline 14 & Illinois & 0.28 & -0.00 & -0.38 & 0.00 & -0.11 \\
\hline 15 & Indiana & 0.11 & 0.00 & -0.23 & 0.00 & -0.12 \\
\hline 16 & Iowa & 0.07 & 0.00 & -0.15 & 0.00 & -0.08 \\
\hline 17 & Kansas & 0.04 & 0.00 & -0.09 & -0.00 & -0.05 \\
\hline 18 & Kentucky & 0.06 & -0.00 & -0.08 & 0.00 & -0.03 \\
\hline 19 & Louisiana & -0.01 & 0.00 & -0.14 & -0.03 & -0.17 \\
\hline 20 & Maine & 0.03 & -0.00 & -0.02 & 0.00 & 0.01 \\
\hline 21 & Maryland & 0.15 & 0.00 & -0.15 & -0.00 & -0.00 \\
\hline 22 & Massachusetts & 0.22 & -0.01 & -0.27 & -0.01 & -0.07 \\
\hline 23 & Michigan & 0.14 & -0.02 & -0.25 & -0.01 & -0.14 \\
\hline 24 & Minnesota & 0.11 & -0.00 & -0.16 & -0.00 & -0.05 \\
\hline 25 & Mississippi & 0.03 & 0.00 & -0.06 & -0.00 & -0.03 \\
\hline 26 & Missouri & 0.09 & -0.00 & -0.08 & 0.00 & 0.01 \\
\hline 27 & Montana & 0.01 & -0.00 & -0.02 & -0.00 & -0.01 \\
\hline 28 & Nebraska & 0.03 & 0.00 & -0.07 & -0.00 & -0.04 \\
\hline 29 & Nevada & 0.02 & 0.00 & -0.03 & 0.00 & -0.01 \\
\hline 30 & New Hampshire & 0.04 & -0.00 & -0.03 & -0.00 & 0.01 \\
\hline 31 & New Jersey & 0.12 & -0.00 & -0.14 & -0.00 & -0.02 \\
\hline 32 & New Mexico & 0.03 & -0.00 & -0.02 & -0.00 & 0.01 \\
\hline 33 & New York & 0.64 & -0.00 & -0.46 & 0.00 & 0.18 \\
\hline 34 & North Carolina & 0.19 & -0.00 & -0.30 & 0.00 & -0.11 \\
\hline 35 & North Dakota & 0.01 & -0.00 & -0.02 & -0.00 & -0.01 \\
\hline 36 & Ohio & 0.22 & -0.00 & -0.27 & -0.00 & -0.06 \\
\hline 37 & Oklahoma & 0.03 & -0.00 & -0.12 & -0.00 & -0.10 \\
\hline 38 & Oregon & 0.11 & 0.00 & -0.12 & -0.00 & -0.01 \\
\hline 39 & Pennsylvania & 0.19 & -0.00 & -0.28 & 0.00 & -0.09 \\
\hline 40 & Rhode Island & 0.02 & -0.00 & -0.02 & 0.00 & 0.00 \\
\hline 41 & South Carolina & 0.08 & -0.00 & -0.08 & -0.00 & -0.00 \\
\hline 42 & South Dakota & 0.01 & -0.00 & -0.04 & 0.00 & -0.02 \\
\hline 43 & Tennessee & 0.14 & -0.00 & -0.16 & -0.00 & -0.02 \\
\hline 44 & Texas & 0.10 & -0.03 & -0.95 & -0.03 & -0.92 \\
\hline 45 & Utah & 0.04 & -0.00 & -0.09 & -0.00 & -0.05 \\
\hline 46 & Vermont & 0.02 & -0.00 & -0.01 & -0.00 & 0.00 \\
\hline 47 & Virginia & 0.22 & 0.00 & -0.21 & -0.00 & 0.01 \\
\hline 48 & Washington & 0.05 & -0.00 & -0.18 & -0.00 & -0.14 \\
\hline 49 & West Virginia & -0.00 & 0.00 & -0.01 & -0.00 & -0.01 \\
\hline 50 & Wisconsin & 0.13 & -0.00 & -0.16 & -0.00 & -0.03 \\
\hline \multirow[t]{2}{*}{51} & Wyoming & -0.00 & -0.01 & -0.03 & -0.01 & -0.05 \\
\hline & Total & 5.65 & -0.07 & -8.75 & -0.10 & -3.26 \\
\hline
\end{tabular}

Table 4: State contributions in percentage 99 ints, 00-07 


\begin{tabular}{|c|c|c|c|c|c|c|}
\hline & State & Comp & Str & Tech & Price & Total \\
\hline 1 & Alabama & 0.03 & -0.00 & -0.03 & 0.00 & -0.00 \\
\hline 2 & Alaska & 0.03 & 0.00 & 0.00 & 0.01 & 0.05 \\
\hline 3 & Arizona & 0.04 & -0.00 & -0.01 & 0.00 & 0.03 \\
\hline 4 & Arkansas & 0.03 & 0.00 & -0.02 & 0.00 & 0.01 \\
\hline 5 & California & 0.90 & -0.01 & -1.01 & 0.00 & -0.11 \\
\hline 6 & Colorado & 0.13 & 0.00 & -0.10 & -0.00 & 0.03 \\
\hline 7 & Connecticut & -0.06 & 0.00 & 0.12 & -0.00 & 0.06 \\
\hline 8 & Delaware & -0.01 & 0.00 & 0.01 & -0.00 & -0.00 \\
\hline 9 & District of Columbia & 0.01 & 0.00 & -0.00 & 0.00 & 0.01 \\
\hline 10 & Florida & 0.08 & 0.00 & -0.07 & 0.00 & 0.01 \\
\hline 11 & Georgia & 0.08 & -0.00 & -0.10 & -0.00 & -0.03 \\
\hline 12 & Hawaii & 0.01 & -0.00 & -0.01 & 0.00 & 0.01 \\
\hline 13 & Idaho & 0.02 & 0.00 & -0.02 & -0.00 & -0.01 \\
\hline 14 & Illinois & 0.03 & -0.00 & -0.11 & 0.00 & -0.09 \\
\hline 15 & Indiana & 0.02 & 0.00 & -0.03 & -0.00 & -0.01 \\
\hline 16 & Iowa & 0.04 & 0.00 & -0.03 & -0.00 & 0.01 \\
\hline 17 & Kansas & 0.03 & 0.00 & -0.04 & 0.00 & -0.01 \\
\hline 18 & Kentucky & 0.01 & -0.00 & -0.02 & 0.00 & -0.00 \\
\hline 19 & Louisiana & 0.04 & 0.00 & 0.09 & 0.00 & 0.14 \\
\hline 20 & Maine & 0.00 & -0.00 & -0.00 & 0.00 & 0.00 \\
\hline 21 & Maryland & 0.07 & -0.00 & -0.12 & 0.00 & -0.06 \\
\hline 22 & Massachusetts & 0.13 & 0.00 & -0.17 & 0.00 & -0.04 \\
\hline 23 & Michigan & -0.02 & -0.00 & -0.02 & 0.00 & -0.04 \\
\hline 24 & Minnesota & 0.10 & -0.00 & -0.12 & 0.00 & -0.02 \\
\hline 25 & Mississippi & 0.01 & 0.00 & 0.00 & -0.00 & 0.01 \\
\hline 26 & Missouri & 0.01 & -0.00 & -0.01 & 0.00 & -0.01 \\
\hline 27 & Montana & 0.02 & 0.00 & -0.01 & 0.00 & 0.01 \\
\hline 28 & Nebraska & 0.02 & 0.00 & -0.04 & -0.00 & -0.02 \\
\hline 29 & Nevada & -0.04 & -0.00 & 0.03 & 0.00 & -0.00 \\
\hline 30 & New Hampshire & 0.02 & -0.00 & -0.03 & -0.00 & -0.01 \\
\hline 31 & New Jersey & -0.02 & -0.01 & -0.05 & 0.00 & -0.08 \\
\hline 32 & New Mexico & 0.04 & 0.00 & -0.02 & 0.00 & 0.02 \\
\hline 33 & New York & -0.23 & 0.00 & -0.37 & 0.00 & -0.59 \\
\hline 34 & North Carolina & 0.04 & 0.00 & -0.05 & -0.00 & -0.01 \\
\hline 35 & North Dakota & 0.05 & -0.00 & -0.04 & 0.00 & 0.01 \\
\hline 36 & Ohio & 0.06 & -0.00 & -0.18 & 0.00 & -0.12 \\
\hline 37 & Oklahoma & 0.14 & 0.00 & -0.13 & 0.01 & 0.02 \\
\hline 38 & Oregon & 0.09 & 0.00 & -0.08 & -0.00 & 0.00 \\
\hline 39 & Pennsylvania & 0.17 & -0.00 & -0.30 & -0.00 & -0.13 \\
\hline 40 & Rhode Island & 0.01 & -0.00 & -0.01 & 0.00 & -0.00 \\
\hline 41 & South Carolina & 0.02 & 0.00 & -0.04 & 0.00 & -0.02 \\
\hline 42 & South Dakota & 0.02 & 0.00 & -0.02 & -0.00 & -0.00 \\
\hline 43 & Tennessee & 0.03 & 0.00 & -0.10 & -0.00 & -0.07 \\
\hline 44 & Texas & 0.75 & -0.06 & -0.46 & 0.06 & 0.28 \\
\hline 45 & Utah & 0.04 & -0.00 & -0.02 & -0.00 & 0.02 \\
\hline 46 & Vermont & 0.01 & -0.00 & -0.01 & 0.00 & -0.00 \\
\hline 47 & Virginia & 0.06 & -0.00 & -0.06 & 0.00 & 0.00 \\
\hline 48 & Washington & 0.20 & -0.00 & -0.22 & -0.00 & -0.03 \\
\hline 49 & West Virginia & 0.02 & 0.00 & -0.02 & 0.00 & -0.01 \\
\hline 50 & Wisconsin & 0.05 & -0.00 & -0.09 & 0.00 & -0.04 \\
\hline \multirow[t]{2}{*}{51} & Wyoming & 0.01 & 0.00 & 0.01 & 0.00 & 0.03 \\
\hline & Total & 3.33 & -0.07 & -4.13 & 0.10 & -0.78 \\
\hline
\end{tabular}

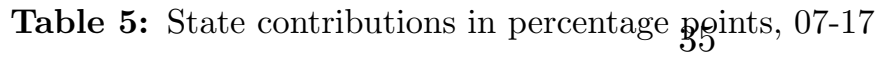




\section{Further figures}

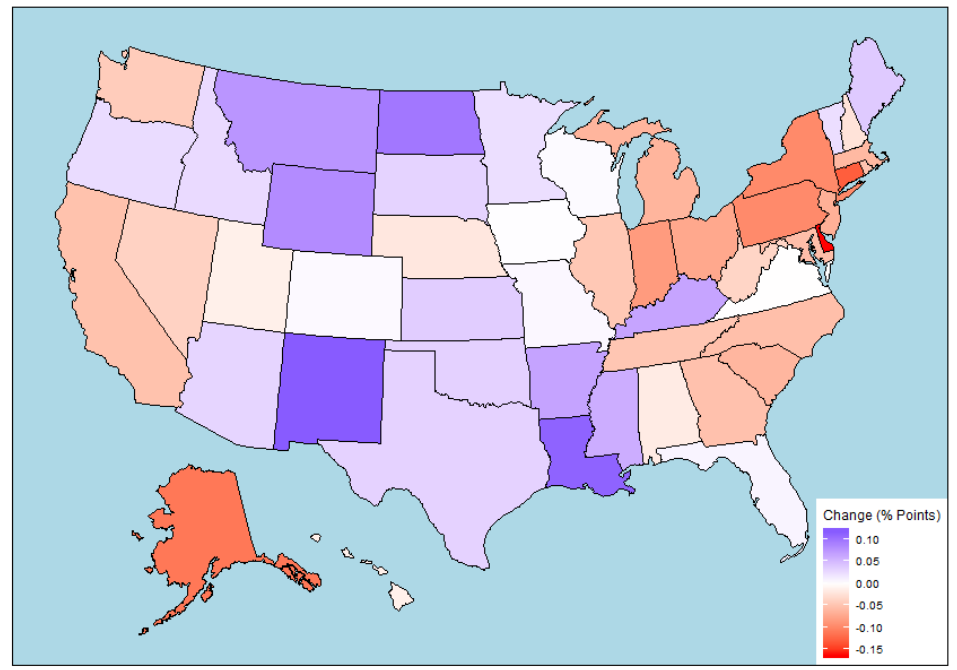

Figure D.1: State share change (1977-2017)
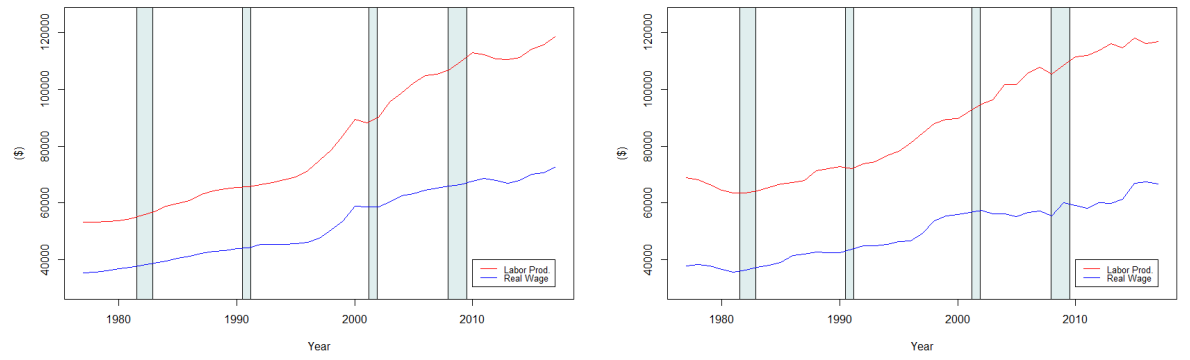

Figure D.2: Labor productivity and real wage trends; California (left) and Texas (right). Recessions depicted by gray bars. 


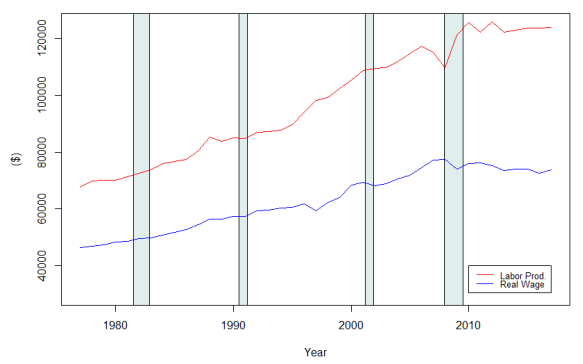

Figure D.3: Labor productivity and real wage trends; New York. Recessions depicted by gray bars.

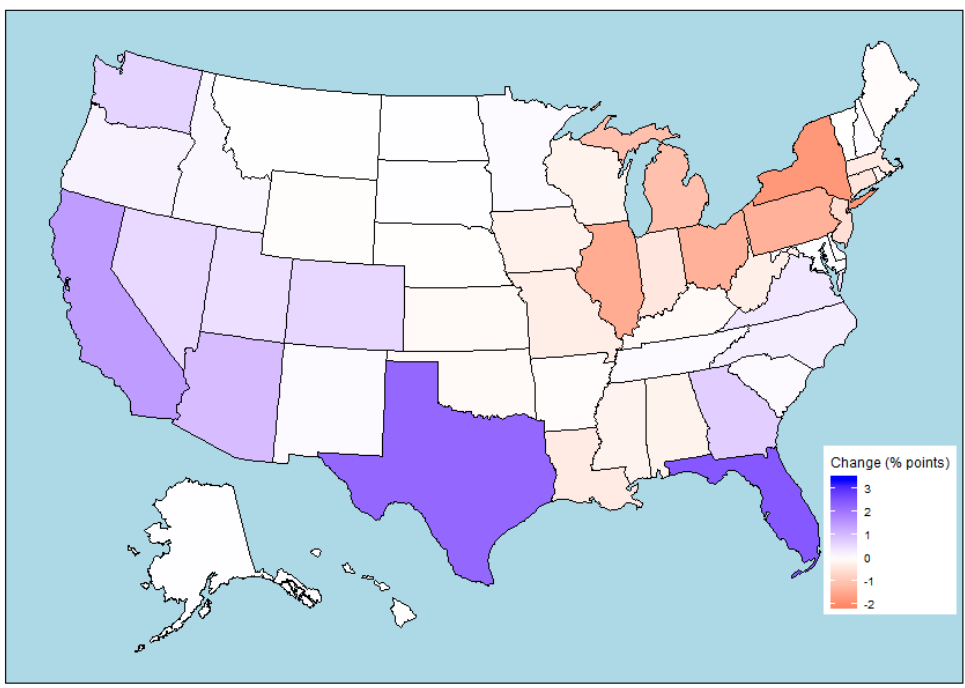

Figure D.4: Change in state share of national employment over period 1977-2017 

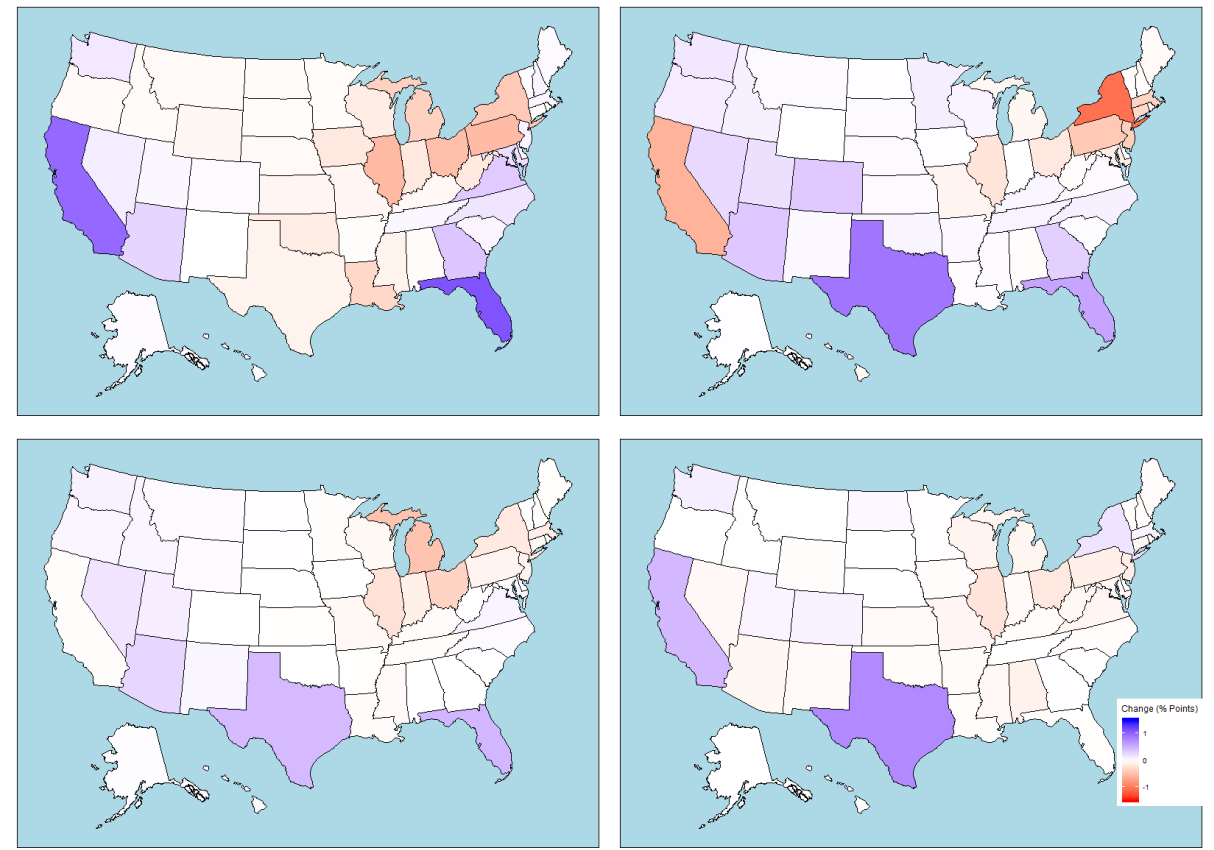

Figure D.5: Change in state share of national employment; clockwise from top-left: 79-89, 89-00, 07-17, 00-07.

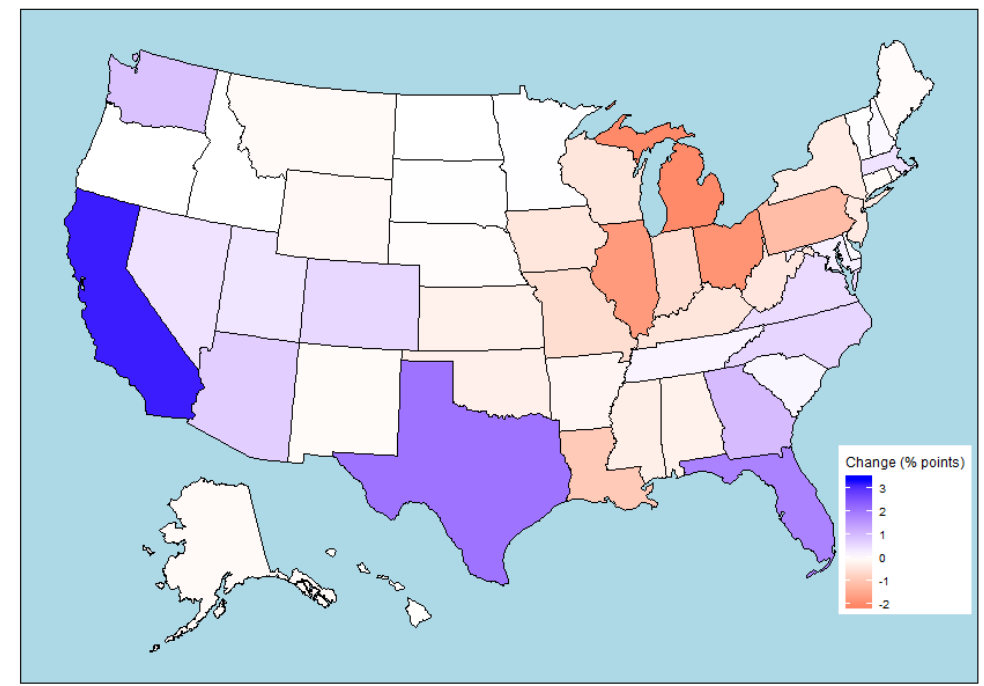

Figure D.6: Change in state share of national value-added in period 1977-2017 

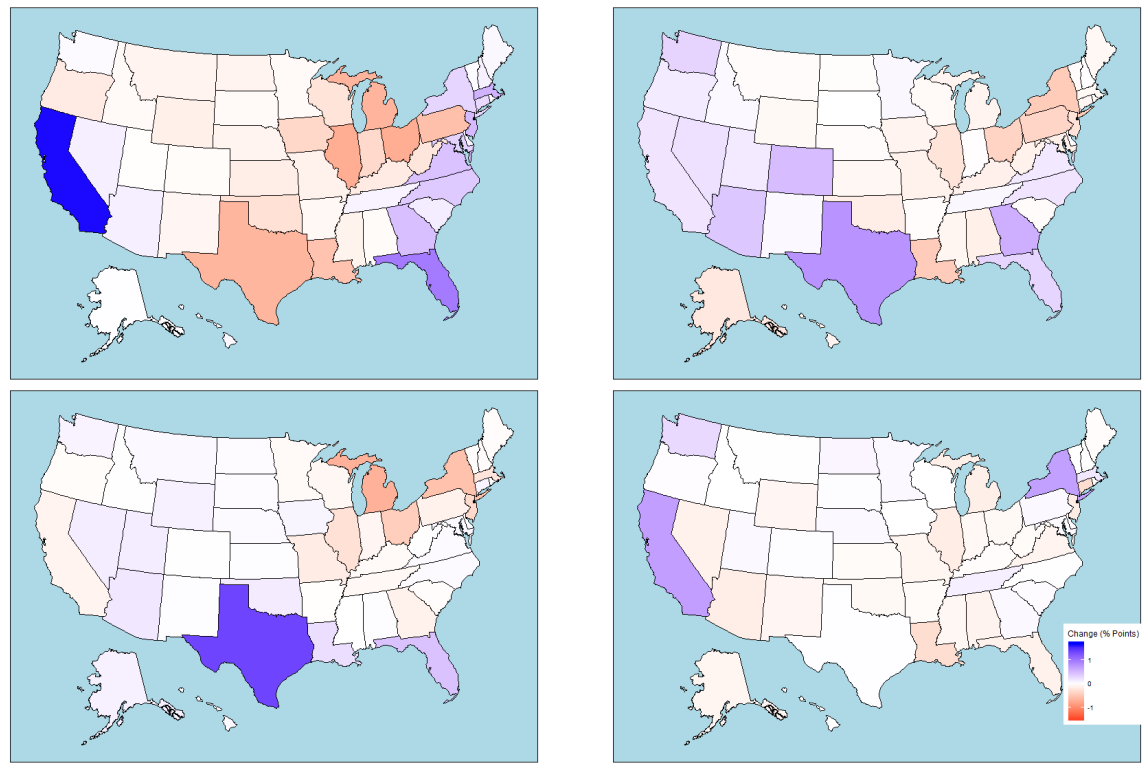

Figure D.7: Change in state share of value added; clockwise from top-left: 79-89, 89-00, 07-17, 00-07. 